\title{
Erosion of coastal archaeological sites on Santa Rosa Island, California
}

\author{
Christopher S. JAZWA ${ }^{1, *}$ and KerRi N. Johnson ${ }^{2}$ \\ ${ }^{1}$ Department of Anthropology, University of Nevada, Reno, 1664 N. Virginia St., MS 0096, Reno, NV 89557-0096 \\ ${ }^{2}$ Department of Geological Sciences and Engineering, University of Nevada, Reno, 1664 N. Virginia St., MS 0172, \\ Reno, NV 89557-0172; Department of Geography, University of California Santa Barbara, \\ 1832 Ellison Hall, Santa Barbara, CA 93106-4060
}

\begin{abstract}
Aвstract.-The damage and loss of coastal archaeological sites from shoreline transgression and other near-coastal processes is common around the world. It negatively impacts our ability to address important research questions including those about the colonization of the New World, which likely occurred along the Pacific Coast. Differences in geomorphic context, annual weather patterns, topography, vegetation, bedrock, and land-use history lead to distinct localized patterns of erosion even within small geographic regions. We assessed near-coastal erosion on Santa Rosa Island, California, by monitoring annual change at 16 controlled points on 11 archaeological sites from 2013 to 2017 and by comparing it to the local geomorphic context and annual weather patterns. Overall, erosion through this period was greatest on the northwest coast of the island, which is directly in the path of prevailing winds and most winter storms, and least on the more protected west and south coasts. The 2016-2017 winter was the rainiest and had the most annual erosion in general; however, erosion at sites along gulley walls was lowest that year. By monitoring annual erosion and weather and associating them with variations in erosional processes, we can better understand threats to valuable cultural resources and take appropriate steps for mitigating their losses and the loss of archaeological data.
\end{abstract}

RESUMEN.-El daño y la desaparición de sitios arqueológicos costeros por transgresiones en la costa y por otros procesos marinos, son comunes en todo el mundo. Este hecho afecta nuestra capacidad para abordar importantes preguntas de investigación, incluyendo la colonización del Nuevo Mundo, que probablemente ocurrió a lo largo de la costa del Pacífico. Las diferencias en el contexto geomorfológico, los patrones climáticos anuales, la topografía, la vegetación, los cimientos y la historia del uso de la tierra conducen a patrones localizados distintivos de erosión, incluso dentro de pequeñas regiones geográficas. Desde el año 2013 al 2017, evaluamos la erosión costera de la isla Santa Rosa, California, monitoreando el cambio anual en un conjunto de 16 puntos controlados en 11 sitios arqueológicos y comparándolo con el contexto geomorfológico local y con los patrones climáticos anuales. En general, la erosión durante este período fue mayor en la costa noroeste de la isla, situada justo en una zona de vientos dominantes y donde se generan la mayoría de las tormentas invernales, y fue menor en las costas oeste y sur, más protegidas. El período invernal del 2016-2017 fue el más lluvioso y, en general, presentó mayor erosión anual. Si monitoreamos la erosión anual y el clima, y los asociamos con las variaciones en los procesos de erosión, podremos comprender mejor las amenazas a los valiosos recursos culturales y tomar las medidas necesarias para mitigar su deterioro y la desaparición de datos arqueológicos.

Erosion is a major threat to the preservation of cultural resources throughout the world, particularly along coastlines where rising sea levels have led to the destruction and inundation of archaeological sites. This is an important concern for our collective understanding of the past because many questions fundamental to archaeology are closely tied to human activity along the world's coastlines. These topics of research include human evolution in Africa (Parkington 1981, van Andel 1989, Stringer
2000, Walter et al. 2000, Erlandson 2002, Bailey et al. 2007, Marean et al. 2007, Klein and Steele 2013, Klein and Bird 2016), colonization of what were then new land masses including North America (Fladmark 1978, 1983, Gruhn 1988, Erlandson 1994, 2001, Erlandson et al. 1996, 2007, 2011, O'Connell and Allen 2012, Smith 2013, Veth et al. 2017), and the development of sociopolitical complexity (Quilter and Stocker 1983, Arnold 1992, 1995, 1997, 2001a, Ames 1994, Jones

*Corresponding author: cjazwa@unr.edu 
2002, Fitzhugh 2003, Arnold and Graesch 2004, Breen and Lane 2004, Glassow 2004, Kennett 2005, Cannon and Yang 2006, Jones and Klar 2007, Kennett et al. 2007, 2009, Kennett and Winterhalder 2008, Fitzhugh and Kennett 2010, Winterhalder et al. 2010, Jazwa 2015, Arnold et al. 2016). In some cases, evidence has already been submerged with postglacial sea-level rise. Therefore, the remaining sites that are at the greatest risk of being lost should be preserved or studied. Because of the importance of determining the threat to these sites, there is a growing literature on modeling coastal erosion and its impact on coastal resources (Bird 1992, Lewis 2000, Fitzpatrick et al. 2006, Murphy et al. 2009, Robinson et al. 2010, Westley et al. 2011, Daire et al. 2012, Reeder et al. 2012, Shi et al. 2012, Reeder-Myers 2015). Our study builds upon these prior studies by including site-specific measurements from a highly threatened coastal location in southern California.

The archaeological research potential of California's northern Channel Islands (NCI) for the understanding of sociopolitical complexity without agriculture (Arnold 1992, Kennett 2005) and human colonization of the Americas along a coastal route (Erlandson et al. 2011, Braje et al. 2013) has long been recognized and has been the subject of extensive research. More broadly, the NCI provide a valuable case study to track the relationship between site location, occupation history, weather, geography, and annual patterns of erosion. However, the cultural materials necessary for addressing these questions are eroding into the ocean around the NCI as sea cliffs retreat along the coast. The NCI are off the coast of Santa Barbara and include 4 islands: San Miguel, Santa Rosa, Santa Cruz, and Anacapa (Fig. 1). The islands are west of the Santa Monica mountain range and have substantial topography, with Diablo Peak on Santa Cruz Island reaching $740 \mathrm{~m}$ above sea level. The largest islands, Santa Cruz and Santa Rosa, have the greatest topographic variation and have diverse environmental conditions within them.

As part of Channel Islands National Park (CHIS) and The Nature Conservancy, the islands are protected from widespread development which could damage or prevent access to archaeological sites. Variation across the islands in topography, geology, and degree of protection from weather events leads to different erosional processes affecting archaeological sites. Our focus for this study is on the erosion of coastal sites around Santa Rosa Island, the second largest of the NCI. The earliest documented settlement sites on the NCI are on Santa Rosa Island, with evidence for thick, dense shell midden deposits as early

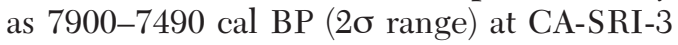
at the mouth of Tecolote Canyon (Kennett et al. 2009, Winterhalder et al. 2010, Jazwa et al. 2016b).

We have chosen to monitor large settlement sites on Santa Rosa Island to determine the rate of loss of archaeological materials from erosion and the risk of further damage. These sites are valuable because many have long chronologies of occupation and therefore have the potential to address important questions about culture change. Many of the largest sites on the NCI with the longest persistent settlements are located at or near the mouths of large drainages where there is access to reliable fresh water and abundant marine subsistence resources (i.e., shellfish, fish, and sea mammals; Kennett 2005, Kennett et al. 2009, Winterhalder et al. 2010, Jazwa et al. 2016b). At the time of historic contact with the Cabrillo expedition in 1542, at least 8 large coastal villages were distributed around the coast of Santa Rosa Island (Johnson 1982, 1993, 2001, Kennett 2005, Glassow et al. 2010).

This paper is a continuation and expansion of the early stages of a long-term project monitoring the erosion at 11 large, permanent coastal settlement sites at 4 locations around the coast of Santa Rosa Island (see Jazwa 2017). These sites were chosen because they are oriented differently to prevailing storm systems: sites at the mouth of Dry and Soledad Canyons are on the northern, windward side of the island in the path of winter storms; sites at the mouth of La Jolla Vieja Canyon are on the southern, leeward side of the island; and sites at the mouths of Cow, Lobos, and Bee Canyons are in regions of intermediate exposure to storms. Focusing on the full range of shoreline aspect to winter storm paths allows a better understanding of threats to site preservation.

Erosion is a competition between the strength of a material to resist erosion and the forces working to erode it. Understanding the geomorphic processes that formed each 


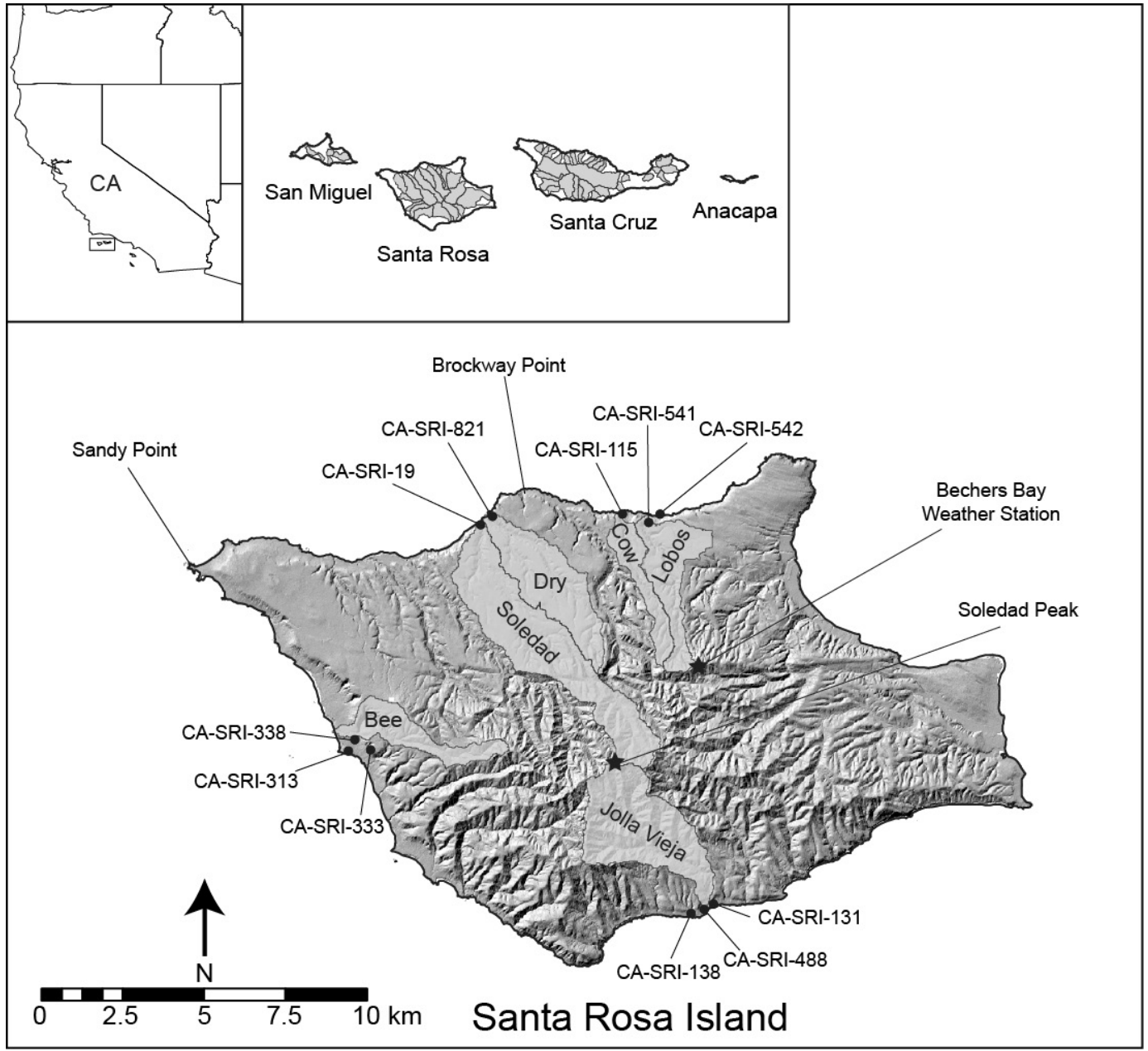

Fig. 1. California's northern Channel Islands, with sites investigated in this study indicated. Watersheds associated with these sites are outlined. The Bechers Bay weather station and landforms discussed in the text are also indicated.

site gives insight into the strength and properties of the material being eroded. Understanding the geomorphic processes eroding each site and which weather variables those processes are sensitive to helps link weather patterns to erosion.

Previous work points to precipitation and wind as 2 leading drivers of site erosion on the NCI (Johnson 1980). In the Mediterranean climate of the NCI, precipitation is concentrated in the winter months (October-April). Winds generally come from the northwest and are slightly stronger in the spring (Fig. 2). Erosion rates are highly variable depending on bedrock strength and coastline geometry. Rates along mainland California range from no measurable erosion over 300 years, to mean annual rates of up to 9 feet per year $(\sim 2.7 \mathrm{~m} /$ year $)$. In many cases, periods of stability are punctuated by rapid retreat during storms, so short- and long-term averages can vary (Griggs et al. 2005). For example, one monitored location on the mainland lost 49 feet $(\sim 15 \mathrm{~m})$ in one year. In this study we are working with a short record of 4 years. Focusing on understanding both the erosive processes that formed sites and those that are eroding sites at the coast puts this record into context.

Coastal sites are not only at risk of erosion because of sea cliff retreat but also because of erosional gullies which can expand through time causing the displacement and loss of 


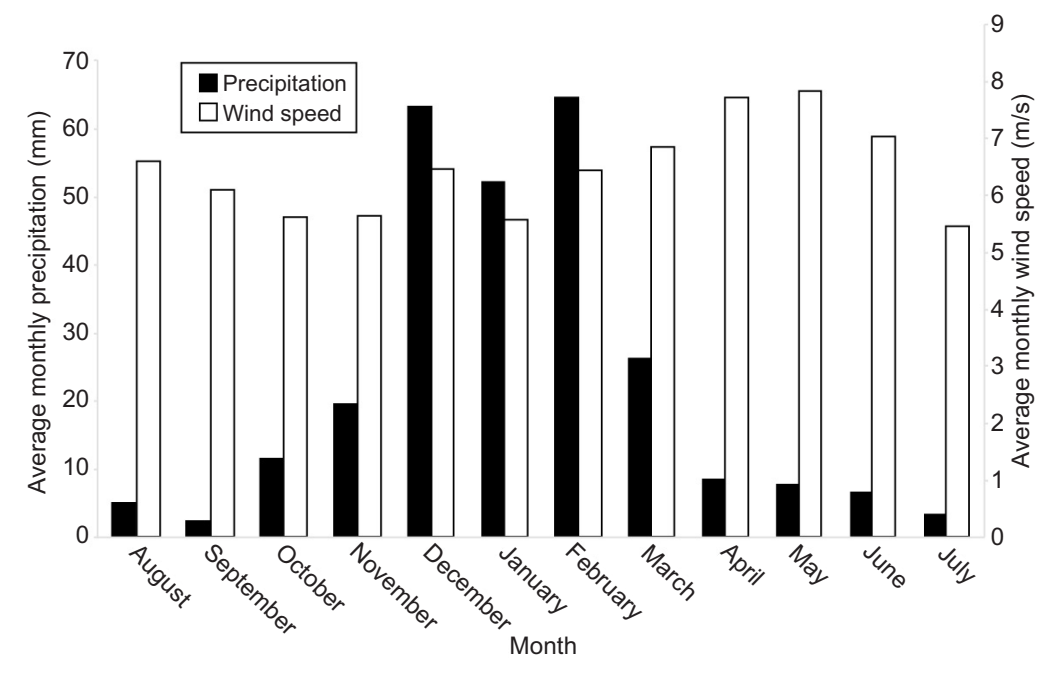

Fig. 2. Average monthly precipitation and wind speed for the 4 years included in this study. Note the $2 y$-axes: precipitation (left) and wind speed (right).

cultural materials. This is partially a result of human activity. Although the NCI have not been subjected to large-scale development like the adjacent mainland, cultural processes have affected the archaeological record, primarily through the introduction of grazing animals. Gullies on the NCI have developed and expanded throughout the 20th century, likely because of ranching (Brumbaugh 1980, Brumbaugh et al. 1982, Perroy et al. 2012), with some evidence that they are continuing to grow (Jazwa 2015, 2017). At least 19 species of nonnative animals, most notably large herbivores, were introduced to the islands in the 19th and 20th centuries (Schoenherr et al. 1999; Rick et al. 2006: 580 , table III). Among the most destructive of these were sheep (Ovis aries), pigs (Sus scrofa), mule deer (Odocoileus hemionus), and cattle (Bos taurus). All have been removed from the NCI in recent years through efforts by staff of CHIS and The Nature Conservancy, but decades of overgrazing have had major detrimental effects on archaeological sites and island landscapes (Johnson 1980, Arnold 2001 b, Rick et al. 2006). The stripping of vegetation from the landscape likely made the soil more susceptible to coastal, fluvial, aeolian, and other sources of erosion on the islands. Further study on the response of gully processes to the removal of grazing and feral animals is needed to predict how these gullies will evolve in the future. Here we focus on erosion by linear retreat of the sharp edges of sea cliffs and gully walls because this type of erosion is common, often exposes a crosssectional view of archaeological sites without disturbing the remaining deposit, and is simple to measure.

The relative effects of erosional processes should differ based on many factors including site location (e.g., sea cliff or gully wall, coastal vs. interior, windward vs. leeward), topography (e.g., slope and cliff shape), lithology (e.g., soft, poorly consolidated materials vs. resistant, well-cemented materials), and nearby features (e.g., canyons, ridgelines, peaks, and streams). Rates of erosion are also strongly influenced by changes in climate including droughts (Raab and Larson 1997, Kennett 2005, Jazwa et al. 2016a), El Niño frequencies (Kennett 2005), and fire regimes (Kennett et al. 2007, 2008), along with natural or precontact, human-induced changes in the fauna of the habitat (Johnson 1980, Arnold 2001b, Agenbroad et al. 2005, Rick et al. 2006, 2008).

Most of the coastal archaeological sites on Santa Rosa Island, including all sites in this study, are situated on marine terraces. Marine terraces are relatively flat, allowing for both ephemeral and permanent settlement. Coastal shell midden sites are common along these landforms, although the larger settlement sites tend to be situated on the lower terraces. All of the sites in this study are along the lower 2 terraces (Fig. 1). The fact that the sites are 
raised from sea level on tectonically uplifted terraces has protected them from marine transgression to some degree but has left them vulnerable to erosion via sea cliff retreat. Gullies have formed through the coastal plain around most of the island (Schumann et al. 2016), exposing and eroding the archaeological sites. It is difficult, however, to determine how many sites have been lost because of erosion.

\section{Geomorphic Context}

When sea level matches the elevation of the land (set by geologic processes like tectonic uplift) for enough time, wave action can bevel a bedrock platform, and sand in the nearshore and beach environment can be deposited on that bedrock platform. These erosional surfaces become marine terraces when the relative elevation of the sea decreases compared to the land and the wave zone abandons the terrace. On Santa Rosa Island, the combination of tectonic uplift and fluctuating sea levels have aligned long enough to form preserved terraces at multiple times/elevations. The 2 prominent marine terraces which now support the archaeological sites we will focus on formed about $80 \mathrm{ka}$ and $120 \mathrm{ka}$ and have since moved above the wave zone by tectonic uplift to $7 \mathrm{~m}$ and $25 \mathrm{~m}$, respectively, above sea level (Muhs et al. 2014, 2015). These terraces are $<500 \mathrm{~m}$ wide in most cases, with older terraces $100 \mathrm{~m}$ or more above them and relatively steep slopes, or terrace risers $\left(>20^{\circ}\right.$ ), between them (Sorlien 1994, Pinter et al. 2001).

Understanding the structure of these terraces can inform the discussion of erosion into the terraces by waves, stream and gully channels, and wind. The characteristic structure of a marine terrace is a near-horizontal bedrock surface with a layer of sand capping it. Over time, soils develop on the surface and windblown dust and sand accumulate. The strength of the lithology of the bedrock that was beveled off by waves varies around Santa Rosa Island and influences a terrace's resistance to marine and channel erosion. The thickness of beach sand capping the terrace, soil development, deposition of sediment onto the terrace, vegetation, and other factors can also influence the resistance of the terrace material to erosion.

\section{Processes of Erosion}

An understanding of the processes of erosion and the deposition of sediment is important for archaeological research. The deposition of sediment is often essential for the preservation of sites because sediment cover can protect archaeological materials from other postdepositional processes. Erosion of sediment frequently exposes new sites, allowing them to be identified by archaeologists, but erosion also poses a threat to the preservation of cultural resources. Understanding the geomorphic context of archaeological sites makes it possible to better predict patterns of erosion that will guide management decisions.

We focus here on understanding the dominant geomorphic processes controlling erosion, including sea cliff retreat, gully incision, and wind erosion, of sites on Santa Rosa Island. We draw on our data set of erosion measurements to provide some end-member examples of how geomorphic context can explain erosion, help predict erosion patterns, and inform management decisions.

\section{Sea Cliff Retreat}

Sea cliff retreat depends on wave action and rock resistance. Specifically, wave energy fractures and detaches cliff rock and removes eroded cliff material from the base of a cliff where the talus rock would otherwise buttress and strengthen the cliff. The strength and erodibility of terrace bedrock underlying marine terrace sand and any subsequent unconsolidated deposits and soil making up the sea cliff is an important predictor of cliff retreat style and rate (e.g., mudstone cliffs are prone to faster retreat than crystalline rock such as intrusive igneous rocks). The direction and magnitude of waves and their orientation with respect to the sea cliff are also important controls on rates of cliff retreat (Adams et al. 2002).

\section{Gully Erosion}

The extent of channels on a landscape is generally thought to be controlled by a competition between the erosion of sediment by the overland flow of surface water concentrated into channels, which carves channels into a landscape, and the transport of sediment by diffusion of hillslope sediment downhill, which smooths a landscape and fills in channels. Changes to this balance that favor 
channelized erosion often stem from an increase in the overland flow of water from heavy precipitation or a decrease in the surface strength of hillslopes. A decrease in hillslope surface strength is common with the loss of vegetation, root strength, or soil structure from trampling, compaction, or tilling (Horton 1945). The NCI experienced a dramatic loss of vegetation when ranching began in the late 19th century. An extensive loss of sediment and the formation of gullies were also observed during this time (Brumbaugh 1980, Brumbaugh et al. 1982, Perroy et al. 2012).

After the initial formation of gullies, gully widening may occur. If gullies are filled in with sediment and vegetation soon after they first incise, they may not undergo much widening. Slumps of sediment sourced by gully widening that are not removed efficiently by channel flow can buttress gully walls and reduce the widening of gully channels. If gully channels continue to incise, however, the undercutting of sidewalls is likely. As with sea cliffs, the material that gullies erode into is an important predictor of erosion rates and styles.

\section{Deflation/Aeolian (Wind) Erosion}

Wind can also erode and deposit sediment. Large dunes and aeolian sand sheets have been emplaced during sea level low stands when marine sediments are exposed to the wind (Muhs et al. 2009). Reworking of this abundance of sand has likely played a role in preserving archaeological sites, but sand is particularly vulnerable to erosion. As with erosion by flowing water, the rate of wind erosion depends on the strength of wind and the amount of vegetation cover on a surface. The loss of vegetation cover makes sand particularly vulnerable to wind erosion. Wind strength is a function of weather patterns and the uninterrupted distance that wind has traveled to pick up speed before arrival at a site (fetch). When assessing the potential for wind erosion, the direction of regional wind patterns is important to consider, as is the orientation of the site's local topography to this wind. For example, a terrace where strong winds generally come off the ocean (a long fetch) would be more prone to erosion. The fetch would be shorter on an island in the lee of another island. In the NCI, northwest winds are most common from frontal systems off the Pacific and easterly wind is caused by high pressure in the Great Basin during Santa Ana conditions. This means that sites on the northwest side of Santa Rosa have more potential for higher-energy wind-waves than the island's eastern coast in the lee of Santa Cruz Island and sites on the south and west coasts of Santa Rosa which are in the lee of the island given prevailing winds.

Wind can usually only transport (erode) noncohesive sediment such as loose sand or dust. When sand is being transported by wind, however, the impact of sand grains hitting a surface (abrasion) can cause erosion of that surface even where soil structure, cohesive sediment (clay), or vegetation would otherwise prevent wind transport. Once detached, the eroded sediment can cause further abrasion downwind. Wind generally transports sand via a process called saltation where particles jump along the surface of the ground. Hop heights of sand grains vary, but these particles are usually concentrated near the ground. Therefore, erosion caused by the impact of these windtransported particles is low to the ground. For example, wind erosion would be stronger on a low-relief hillslope behind a sandy beach than it would be on a sea cliff high above a beach where wind is sand free (Anderson 1986).

By identifying the dominant geomorphic processes causing erosion at each site, a set of contributing conditions can be used to predict where the threat of erosion is greatest. For example, sea cliff lithology and orientation to dominant wave patterns would help determine relative loss rates of cultural resources exposed in sea cliffs. If a site is exposed along a gully, sedimentation within that gully and vegetative cover of the adjacent hillslope may be the strongest predictors of gully widening and erosion of the site. The processes described here are of specific relevance to the sites on Santa Rosa Island described in this study but are by no means an exhaustive list of possible geomorphic processes that pose a threat to archaeological sites. In other locations different geomorphic processes and therefore different sets of conditions may better predict erosion and the loss of cultural resources.

\section{Methods}

\section{Weather Monitoring}

Hourly data from a weather station at Bechers Bay in northeastern Santa Rosa Island 


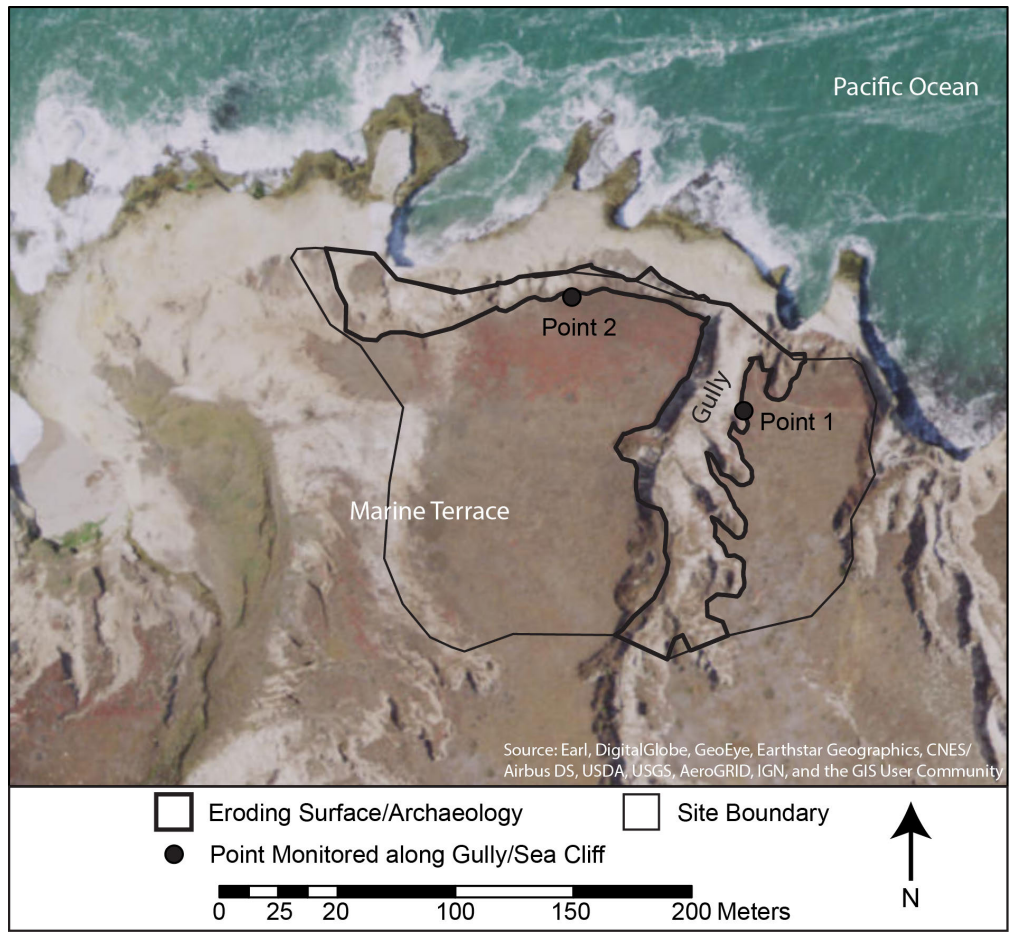

Fig. 3. Example map of site erosion for CA-SRI-115 superposed over a 50-m USGS topographic contour map of the Santa Rosa Island north quad. A heavy black line outlines the part of the site that is actively eroding, with materials out of context on the surface or gully formation.

(Fig. 1) have been collected by CHIS since April 1990. These data are available online from the Western Regional Climate Center of the Desert Research Institute (http://www .wrcc.dri.edu). In this study, we have incorporated hourly and daily data from this database for precipitation and wind from 1 August 2013 to 31 July 2017. The total monthly and annual (August-July) precipitation amounts have been compiled for this range. We also calculated the number of days and individual hours with at least $1 \mathrm{~mm}$ of rain (rainy days/hours) and those days and hours with at least $5 \mathrm{~mm}$ of rain (very rainy days/hours) for each month and year. Similarly, we calculated the daily average wind speed and the maximum wind gust for each month and year (August-July), along with the number of days each month and year with an average wind speed over $10 \mathrm{~m} / \mathrm{s}$ and/or maximum wind gusts over $20 \mathrm{~m} / \mathrm{s}$. While a single rainfall measurement from the Bechers Bay station is a good proxy for the rest of the island because of the island's relatively small size, variations in wind patterns across the island make that proxy substantially more limiting. Because more precise measurements are unavailable, wind data are treated acknowledging this. We make qualitative interpretations about geographic variation in wind erosion based on prevailing wind direction and these wind data.

\section{Extent of Archaeological Site Erosion}

We determined the proportion of the surface area of each site that has evidence of erosion using a handheld GPS unit and aerial photographs. In 2013 we used a Trimble ${ }^{\circledR}$ Geo7X handheld GPS unit to generate maps of each of the 11 sites (Fig. 3). Using the Trimble system, we generated polygons of the overall site distributions and the extent of surface erosion. Data on surface erosion were supplemented using aerial photos taken in 2014 that are available in ArcGIS 10. These distributions provide a method for comparing the long-term effects of erosion at each of the sites. We used the proportion of the surface area that is eroding in each site (eroding 
surface area divided by overall archaeological site surface area) as an indicator of active erosion and the potential for continued loss of cultural material at each of the sites. There are 2 important limitations to this approach. First, we do not know the original lateral extent of any of the sites investigated here prior to erosion or sea cliff retreat. Unlike at some interior sites, there is no way to estimate the original size of any of these sites. Second, because subsurface testing at these sites has been limited, we do not know the remaining lateral extent of the sites.

\section{Horizontal Retreat Measurements of Gully Sidewalls and Sea Cliffs}

We chose 16 specific points on the landscape (4 points in each geographic area) along gully sidewalls and sea cliffs to monitor annual erosion. For Dry and Soledad Canyons, there are 3 monitoring points at CA-SRI-19 and 1 at CA-SRI-821. For Cow and Lobos Canyons, there are 2 points at CA-SRI-115 and 1 each at CA-SRI-541 and CA-SRI-542. For Bee Canyon, we placed 2 points at CA-SRI-313 and 1 each at CA-SRI-333 and CA-SRI-338. For La Jolla Vieja Canyon, we placed 2 points at CA-SRI-138 and 1 each at CA-SRI-131 and CA-SRI-488. We placed a metal stake in the ground $1 \mathrm{~m}$ back from the erosional scarp (e.g., gully sidewall or sea cliff) at each chosen location. Stakes were initially placed in July 2013. Their distances from the eroding surfaces were measured again in May-June 2014, August 2015, August 2016, and August 2017 to monitor annual retreat.

\section{RESUlTS}

\section{3-2017 Annual Weather Patterns}

Differences in weather patterns among the 4 years in this study are reflected by precipitation and wind data. The winter of 2015-2016 was during a strong El Niño year, with sea surface temperature anomalies during the fall and winter among the highest in recorded history (NOAA 2016a, NASA 2015). An important implication of El Niño conditions for archaeological site erosion is the association with strong coastal storms in California (Ramage 1986, Casey et al. 1989, Philander 1990, Haston and Michaelson 1994, Sandweiss et al. 2001, Kennett 2005). Though strong storms tend to be more common during El Niño events, this is not always the case (Ramage 1986, Philander 1990, Haston and Michaelson 1994, Cobb et al. 2003, NOAA 2016a). The 2015-2016 year, for example, was only the third rainiest of the 4 years in terms of total precipitation despite having a very strong El Niño (Table 1, Fig. 4). The year 2016-2017, being a weak La Niña, was by far the wettest year in both total rainfall and frequency of heavy rains and one of the windiest (Fig. 5).

During 2013-2014, there was a total of $173.3 \mathrm{~mm}$ of precipitation, with $18 \mathrm{~d}$ and $37 \mathrm{~h}$ with at least $1 \mathrm{~mm}$ of rainfall and $8 \mathrm{~d}$ and $6 \mathrm{~h}$ with at least $5 \mathrm{~mm}$ of rainfall (Table 1). The rainy season began in November, which was the first month to have more than $10 \mathrm{~mm}$ of total precipitation and more than $5 \mathrm{~mm}$ in a single day $(14.2 \mathrm{~mm})$ and a single hour $(5.6 \mathrm{~mm})$. However, this precipitation was largely limited to a single day and rainfall was minimal in December and January. The peak in precipitation during 2013-2014 occurred in February with $93.0 \mathrm{~mm}$ of rainfall and $6 \mathrm{~d}$ with more than $5 \mathrm{~mm}$.

The 2014-2015 rainy season was wetter than the previous year, with a total of $283.2 \mathrm{~mm}$ of rain. Additionally, the rainy season peaked earlier than in the other 3 years. A total of $17.0 \mathrm{~mm}$ of precipitation fell in October 2014 , but it was mostly confined to a single day $(15.2 \mathrm{~mm})$ and largely a single hour $(12.5 \mathrm{~mm})$. Precipitation peaked in December at $188.2 \mathrm{~mm}$, which was more than the 2013-2014 annual total and only $14.1 \mathrm{~mm}$ less than the 2015-2016 annual total. In December there were $8 \mathrm{~d}$ and $39 \mathrm{~h}$ in which more than $1 \mathrm{~mm}$ of rain fell and $4 \mathrm{~d}$ and $11 \mathrm{~h}$ in which more than $5 \mathrm{~mm}$ of rain fell, making December 2014 the rainiest month of the entire study. Although consistent rains continued through February, $64 \%$ of the total annual precipitation fell in December.

The 2015-2016 El Niño year was intermediate in terms of total annual rainfall and the number of especially wet hours. This year differed from the previous 2 years in that rainfall was much more consistent throughout the winter. Every month from November to April had at least $10 \mathrm{~mm}$ of rainfall, with a maximum of $60.4 \mathrm{~mm}$ in March (Table 1). The 2015-2016 year had 13 more rainy days (with at least $1 \mathrm{~mm}$ of precipitation) than 2014-2015, but 14 fewer rainy hours. Though 2014-2015 had more overall precipitation than 2015-2016, it was largely confined to storms in a single 
TABLE 1. Precipitation data from the Bechers Bay weather station on Santa Rosa Island. Data are compiled monthly and annually (August-July) for 2013-2014, 2014-2015, 2015-2016, and 2016-2017.

\begin{tabular}{|c|c|c|c|c|c|c|c|c|}
\hline \multirow[b]{2}{*}{ Year } & \multirow[b]{2}{*}{ Month } & \multirow{2}{*}{$\begin{array}{c}\text { Total } \\
\text { precipitation } \\
(\mathrm{mm})\end{array}$} & \multicolumn{3}{|c|}{ Daily } & \multicolumn{3}{|c|}{ Hourly } \\
\hline & & & $\begin{array}{c}\text { At least } \\
1 \mathrm{~mm}\end{array}$ & $\begin{array}{l}\text { At least } \\
5 \mathrm{~mm}\end{array}$ & $\begin{array}{l}\text { Maximum } \\
(\mathrm{mm})\end{array}$ & $\begin{array}{l}\text { At least } \\
1 \mathrm{~mm}\end{array}$ & $\begin{array}{c}\text { At least } \\
5 \mathrm{~mm}\end{array}$ & $\begin{array}{l}\text { Maximum } \\
\quad(\mathrm{mm})\end{array}$ \\
\hline \multirow[t]{5}{*}{2013} & August & 6.1 & 1 & 0 & 1 & 0 & 0 & 0.3 \\
\hline & September & 2.3 & 0 & 0 & 0.5 & 0 & 0 & 0.3 \\
\hline & October & 6.6 & 1 & 0 & 3.3 & 1 & 0 & 2.3 \\
\hline & November & 17.8 & 2 & 1 & 14.2 & 4 & 1 & 5.6 \\
\hline & December & 4.3 & 2 & 0 & 2 & 1 & 0 & 1.1 \\
\hline \multirow[t]{7}{*}{2014} & January & 1.3 & 0 & 0 & 0.5 & 0 & 0 & 0.3 \\
\hline & February & 93 & 6 & 6 & 28.5 & 24 & 4 & 12.9 \\
\hline & March & 19.6 & 3 & 1 & 10.7 & 3 & 1 & 6.6 \\
\hline & April & 10.2 & 3 & 0 & 4.8 & 4 & 0 & 2 \\
\hline & May & 3 & 0 & 0 & 0.5 & 0 & 0 & 0.3 \\
\hline & June & 6.1 & 0 & 0 & 0.5 & 0 & 0 & 0.3 \\
\hline & July & 3.3 & 0 & 0 & 0.5 & 0 & 0 & 0.3 \\
\hline 2013-2014 & August-July & 173.3 & 18 & 8 & 28.5 & 37 & 6 & 12.9 \\
\hline \multirow[t]{5}{*}{2014} & August & 2.8 & 0 & 0 & 0.5 & 0 & 0 & 0.3 \\
\hline & September & 3.5 & 0 & 0 & 0.8 & 0 & 0 & 0.3 \\
\hline & October & 17 & 1 & 1 & 15.2 & 2 & 1 & 12.5 \\
\hline & November & 7.4 & 2 & 1 & 5.1 & 2 & 0 & 3.1 \\
\hline & December & 188.2 & 8 & 4 & 89.2 & 39 & 11 & 12.7 \\
\hline \multirow[t]{7}{*}{2015} & January & 15.5 & 2 & 1 & 11.7 & 4 & 0 & 1.5 \\
\hline & February & 17.8 & 3 & 2 & 7.1 & 3 & 0 & 1.8 \\
\hline & March & 2.3 & 0 & 0 & 0.5 & 0 & 0 & 0.5 \\
\hline & April & 4.8 & 2 & 0 & 2.5 & 2 & 0 & 2 \\
\hline & May & 8.1 & 1 & 1 & 5.3 & 2 & 0 & 2.8 \\
\hline & June & 11.2 & 1 & 7 & 5.8 & 1 & 0 & 2.6 \\
\hline & July & 4.8 & 0 & 3 & 0.8 & 0 & 0 & 0.3 \\
\hline 2014-2015 & August-July & 283.2 & 20 & 11 & 89.2 & 55 & 12 & 12.7 \\
\hline \multirow{5}{*}{2015} & August & 4.5 & 0 & 0 & 0.5 & 0 & 0 & 0.3 \\
\hline & September & 1.8 & 1 & 0 & 1 & 0 & 0 & 0.5 \\
\hline & October & 8.4 & 1 & 1 & 7.1 & 3 & 0 & 3.6 \\
\hline & November & 14.7 & 5 & 1 & 5.6 & 5 & 0 & 2.8 \\
\hline & December & 19.3 & 5 & 1 & 6.1 & 2 & 0 & 3.3 \\
\hline \multirow[t]{7}{*}{2016} & January & 57.4 & 10 & 3 & 27.4 & 15 & 2 & 8.1 \\
\hline & February & 10.7 & 2 & 1 & 5.8 & 1 & 0 & 1.7 \\
\hline & March & 60.4 & 6 & 4 & 15.8 & 12 & 2 & 8.1 \\
\hline & April & 10.1 & 2 & 1 & 6.9 & 2 & 0 & 2.8 \\
\hline & May & 7.1 & 1 & 0 & 3.6 & 1 & 0 & 2.5 \\
\hline & June & 4.8 & 0 & 0 & 0.8 & 0 & 0 & 0.3 \\
\hline & July & 3 & 0 & 0 & 0.5 & 0 & 0 & 0.3 \\
\hline 2015-2016 & August-July & 202.3 & 33 & 12 & 27.4 & 41 & 4 & 8.1 \\
\hline \multirow[t]{5}{*}{2016} & August & 7.1 & 0 & 0 & 0.8 & 0 & 0 & 0.3 \\
\hline & September & 1.8 & 0 & 0 & 0.5 & 0 & 0 & 0.3 \\
\hline & October & 14.2 & 5 & 0 & 3.6 & 5 & 0 & 1.3 \\
\hline & November & 38.1 & 4 & 1 & 30.5 & 10 & 1 & 7.1 \\
\hline & December & 40.9 & 5 & 2 & 16.3 & 14 & 1 & 7.6 \\
\hline \multirow{7}{*}{2017} & January & 134.4 & 12 & 8 & 61.5 & 35 & 4 & 13.7 \\
\hline & February & 136.9 & 14 & 7 & 57.9 & 43 & 7 & 8.6 \\
\hline & March & 22.6 & 3 & 1 & 15.2 & 10 & 0 & 3 \\
\hline & April & 8.9 & 4 & 0 & 2 & 0 & 0 & 0.5 \\
\hline & May & 12.2 & 2 & 1 & 8.1 & 5 & 0 & 1.8 \\
\hline & June & 4.3 & 0 & 0 & 0.8 & 0 & 0 & 0.3 \\
\hline & July & 1.8 & 0 & 0 & 0.3 & 0 & 0 & 0.3 \\
\hline 2016-2017 & August-July & 422.9 & 49 & 20 & 61.5 & 122 & 13 & 13.7 \\
\hline
\end{tabular}




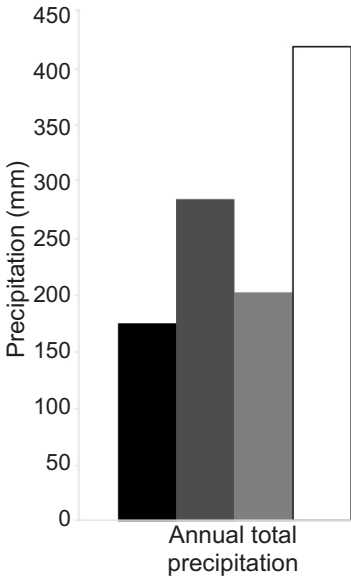

Fig. 4. Annual total precipitation (left) and daily maximum precipitation for each year (right) on Santa Rosa Island. Data are from the Western Regional Climate Center of the Desert Research Institute, Reno, Nevada.

month. During the 2015-2016 El Niño, Santa Rosa Island had more rainy days than in previous years, but peaks in rainfall were less intense overall.

By far the rainiest year in the study was 2016-2017 with a total of $422.9 \mathrm{~mm}$ of precipitation (Table 1, Fig. 4). Rain was consistent throughout the winter, but there were especially wet and stormy months as in 2014-2015. This caused erosion and road closures (some of which remained in place through the summer months) across Santa Rosa Island. The rainiest months were January and February, which each had over $134 \mathrm{~mm}$ of precipitation. At least 20 $\mathrm{mm}$ fell each month from November to March. Overall there were $49 \mathrm{~d}$ and $122 \mathrm{~h}$ with at least $1 \mathrm{~mm}$ of precipitation and $20 \mathrm{~d}$ and $13 \mathrm{~h}$ with at least $5 \mathrm{~mm}$ of precipitation. These numbers were the highest in the study despite 20162017 being the year after the strong El Niño.

Wind was weakest overall during 2014-2015 and strongest during the 2015-2016 El Niño year and the 2016-2017 year (Table 2, Fig. 6). The daily average wind speed during 2013-2014 was $6.5 \mathrm{~m} / \mathrm{s}$, with a maximum daily average of $14.9 \mathrm{~m} / \mathrm{s}$. The highest daily average wind speeds were from February through May, with the highest monthly average of $8.6 \mathrm{~m} / \mathrm{s}$ in May. The highest wind gusts also occurred from February through May. The highest average daily maximum wind gust of $16.8 \mathrm{~m} / \mathrm{s}$ occurred in May, but the annual maximum wind gust of $30.9 \mathrm{~m} / \mathrm{s}$ occurred in February, coincident with the peak in rainfall.

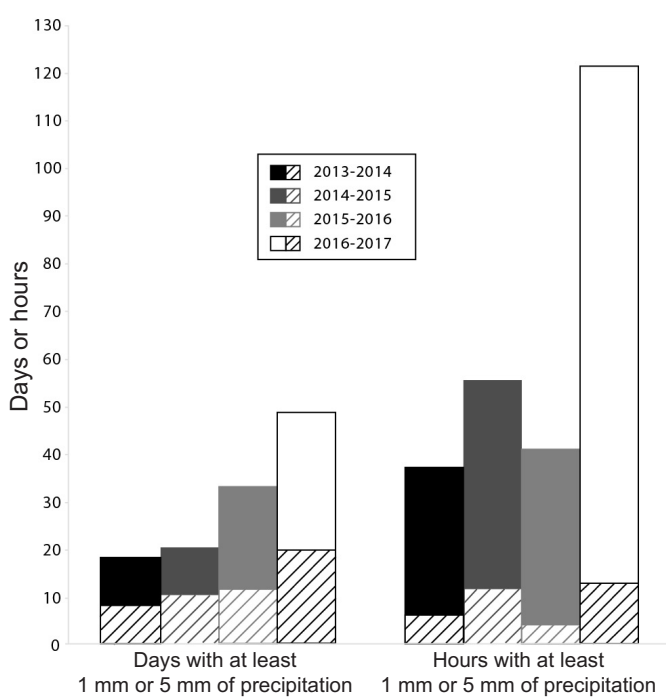

Fig. 5. Total number of rainy days (left) and hours (right) for each year of this study. Rainy days and hours are defined as having $1 \mathrm{~mm}$ (full bars) or $5 \mathrm{~mm}$ (hatched bars) of precipitation.

Overall, 2014-2015 was less windy than other years. The daily average wind speed for the year was $6.0 \mathrm{~m} / \mathrm{s}$, with a maximum daily average of $13.2 \mathrm{~m} / \mathrm{s}$. February through May made up the windy season, with the maximum monthly average wind speed of $7.9 \mathrm{~m} / \mathrm{s}$ in May. The annual maximum wind gust of $28.6 \mathrm{~m} / \mathrm{s}$ occurred in December, which coincided with heavy rainfall. The highest average daily maximum wind gust of $15.6 \mathrm{~m} / \mathrm{s}$ occurred in May, although the value of $14.9 \mathrm{~m} / \mathrm{s}$ for December was uncharacteristically high for that month. Gusts were concentrated in December, with $8 \mathrm{~d}$ surpassing $20 \mathrm{~m} / \mathrm{s}$, reflecting the same storms apparent in the monthly precipitation data.

The 2015-2016 El Niño year was the windiest in this study in terms of daily average wind speed and wind gust. The annual daily average wind speed was $6.7 \mathrm{~m} / \mathrm{s}$, with a maximum of $16.1 \mathrm{~m} / \mathrm{s}$. The strongest winds occurred from December through June, with the maximum monthly average wind speed of $8.3 \mathrm{~m} / \mathrm{s}$ in March, the month with the greatest monthly precipitation for the year. The annual maximum wind gust of $32.2 \mathrm{~m} / \mathrm{s}$ was stronger than either of the previous years.

During 2016-2017, daily average wind speeds and wind gusts were lower than the previous year but the maxima were higher. 
TABLE 2. Wind data from the Bechers Bay weather station on Santa Rosa Island. Data are compiled monthly and annually (August-July) for 2013-2014, 2014-2015, 2015-2016, and 2016-2017.

\begin{tabular}{|c|c|c|c|c|c|c|c|}
\hline \multirow[b]{2}{*}{ Year } & \multirow[b]{2}{*}{ Month } & \multicolumn{3}{|c|}{ Daily average wind speed } & \multicolumn{3}{|c|}{ Daily maximum wind gust } \\
\hline & & $\begin{array}{c}\text { Average } \\
(\mathrm{m} / \mathrm{s})\end{array}$ & $\begin{array}{c}\text { At least } \\
10 \mathrm{~m} / \mathrm{s}\end{array}$ & $\underset{(\mathrm{m} / \mathrm{s})}{\operatorname{Maximum}}$ & $\begin{array}{c}\text { Average } \\
(\mathrm{m} / \mathrm{s})\end{array}$ & $\begin{array}{l}\text { At least } \\
20 \mathrm{~m} / \mathrm{s}\end{array}$ & $\begin{array}{c}\text { Maximum } \\
(\mathrm{m} / \mathrm{s})\end{array}$ \\
\hline 2013 & $\begin{array}{l}\text { August } \\
\text { September } \\
\text { October } \\
\text { November } \\
\text { December }\end{array}$ & $\begin{array}{l}6.8 \\
6.6 \\
5.4 \\
5.2 \\
5.6\end{array}$ & $\begin{array}{l}3 \\
3 \\
1 \\
2 \\
4\end{array}$ & \begin{tabular}{l|}
10.6 \\
13 \\
10.4 \\
11.6 \\
12.3
\end{tabular} & $\begin{array}{l}13 \\
14 \\
12.1 \\
12.2 \\
12.6\end{array}$ & $\begin{array}{l}0 \\
3 \\
0 \\
1 \\
4\end{array}$ & $\begin{array}{l}18.8 \\
22.8 \\
19.7 \\
20.1 \\
21.9\end{array}$ \\
\hline 2014 & $\begin{array}{l}\text { January } \\
\text { February } \\
\text { March } \\
\text { April } \\
\text { May } \\
\text { June } \\
\text { July }\end{array}$ & $\begin{array}{l}5.5 \\
7.1 \\
6.9 \\
7.1 \\
8.6 \\
7.1 \\
5.7\end{array}$ & $\begin{array}{r}2 \\
6 \\
4 \\
6 \\
13 \\
6 \\
3\end{array}$ & $\begin{array}{l}10.6 \\
13.4 \\
12.9 \\
13.2 \\
14.9 \\
11.7 \\
11.9\end{array}$ & $\begin{array}{l}12.9 \\
15.7 \\
15.2 \\
14.9 \\
16.8 \\
14.3 \\
11.9\end{array}$ & $\begin{array}{l}1 \\
5 \\
4 \\
4 \\
9 \\
3 \\
1\end{array}$ & $\begin{array}{l}24.6 \\
30.9 \\
25.9 \\
22.4 \\
25.5 \\
21.9 \\
21\end{array}$ \\
\hline 2013-2014 & August-July & 6.5 & 53 & 14.9 & 13.8 & 35 & 30.9 \\
\hline 2014 & $\begin{array}{l}\text { August } \\
\text { September } \\
\text { October } \\
\text { November } \\
\text { December }\end{array}$ & $\begin{array}{l}5.4 \\
6.9 \\
5 \\
5.4 \\
6.4 \\
\end{array}$ & $\begin{array}{l}0 \\
2 \\
1 \\
1 \\
3\end{array}$ & $\begin{array}{r}9.3 \\
12.4 \\
10.2 \\
12.6 \\
12.2\end{array}$ & $\begin{array}{l}11.5 \\
13.4 \\
11.1 \\
12.3 \\
14.9\end{array}$ & $\begin{array}{l}1 \\
2 \\
1 \\
1 \\
8\end{array}$ & $\begin{array}{l}21.5 \\
22.8 \\
20.1 \\
22.4 \\
28.6\end{array}$ \\
\hline 2015 & $\begin{array}{l}\text { January } \\
\text { February } \\
\text { March } \\
\text { April } \\
\text { May } \\
\text { June } \\
\text { July }\end{array}$ & $\begin{array}{l}4.1 \\
5.7 \\
5.5 \\
7.1 \\
7.9 \\
6.7 \\
6\end{array}$ & $\begin{array}{l}0 \\
3 \\
3 \\
6 \\
6 \\
7 \\
3\end{array}$ & \begin{tabular}{r|r}
7.9 \\
12.7 \\
13.2 \\
12.4 \\
12.5 \\
11.2 \\
12.6
\end{tabular} & $\begin{array}{l}10.1 \\
12.7 \\
12.8 \\
15.1 \\
15.6 \\
13.8 \\
12.3\end{array}$ & $\begin{array}{l}0 \\
2 \\
3 \\
5 \\
5 \\
1 \\
0\end{array}$ & $\begin{array}{l}16.5 \\
22.8 \\
22.8 \\
24.6 \\
21.5 \\
21.5 \\
19.7\end{array}$ \\
\hline 2014-2015 & August-July & 6 & 35 & 13.2 & 13 & 29 & 28.6 \\
\hline 2015 & $\begin{array}{l}\text { August } \\
\text { September } \\
\text { October } \\
\text { November } \\
\text { December }\end{array}$ & $\begin{array}{l}7.6 \\
5 \\
5.9 \\
5.9 \\
7.6\end{array}$ & $\begin{array}{l}8 \\
1 \\
3 \\
2 \\
8\end{array}$ & $\begin{array}{l}12 \\
11.1 \\
11.8 \\
12.4 \\
15.4\end{array}$ & $\begin{array}{l}15 \\
11.1 \\
12.9 \\
13.2 \\
16.2\end{array}$ & $\begin{array}{l}3 \\
0 \\
4 \\
2 \\
6\end{array}$ & $\begin{array}{l}21 \\
18.3 \\
20.6 \\
25.9 \\
26.8\end{array}$ \\
\hline 2016 & $\begin{array}{l}\text { January } \\
\text { February } \\
\text { March } \\
\text { April } \\
\text { May } \\
\text { June } \\
\text { July }\end{array}$ & $\begin{array}{l}6.7 \\
5.8 \\
8.3 \\
8.2 \\
6.8 \\
6.7 \\
5.3\end{array}$ & $\begin{array}{l}6 \\
2 \\
7 \\
9 \\
9 \\
3 \\
1\end{array}$ & $\begin{array}{l}14.8 \\
13.2 \\
14.4 \\
16.1 \\
13.1 \\
13.6 \\
10.9\end{array}$ & $\begin{array}{l}15.3 \\
13.1 \\
17.1 \\
16.6 \\
14.2 \\
14.4 \\
11.9\end{array}$ & $\begin{array}{r}4 \\
1 \\
8 \\
11 \\
6 \\
4 \\
2\end{array}$ & $\begin{array}{l}30.4 \\
32.2 \\
27.3 \\
26.4 \\
21.5 \\
22.8 \\
21\end{array}$ \\
\hline $2015-2016$ & August-July & 6.7 & 59 & 16.1 & 14.3 & 51 & 32.2 \\
\hline 2016 & $\begin{array}{l}\text { August } \\
\text { September } \\
\text { October } \\
\text { November } \\
\text { December }\end{array}$ & $\begin{array}{l}6.5 \\
5.8 \\
6.1 \\
5.9 \\
6.2\end{array}$ & $\begin{array}{l}3 \\
2 \\
4 \\
5 \\
3\end{array}$ & $\begin{array}{l}11 \\
13.5 \\
12.9 \\
14.8 \\
12.6\end{array}$ & $\begin{array}{l}13 \\
12.7 \\
13.3 \\
13.6 \\
13.2\end{array}$ & $\begin{array}{l}0 \\
4 \\
2 \\
3 \\
2\end{array}$ & $\begin{array}{l}19.2 \\
21.9 \\
23.3 \\
25 \\
22.4\end{array}$ \\
\hline 2017 & $\begin{array}{l}\text { January } \\
\text { February } \\
\text { March } \\
\text { April } \\
\text { May } \\
\text { June } \\
\text { July }\end{array}$ & $\begin{array}{l}5.9 \\
7.1 \\
6.7 \\
8.5 \\
8 \\
7.6 \\
4.7\end{array}$ & $\begin{array}{r}4 \\
7 \\
6 \\
10 \\
8 \\
8 \\
1\end{array}$ & $\begin{array}{l}11 \\
12.9 \\
15.5 \\
16.6 \\
15.8 \\
14.2 \\
10\end{array}$ & $\begin{array}{l}14.9 \\
15.6 \\
14.4 \\
17 \\
16 \\
15.2 \\
11\end{array}$ & $\begin{array}{r}4 \\
6 \\
7 \\
11 \\
9 \\
6 \\
0\end{array}$ & $\begin{array}{l}30 \\
34 \\
28.2 \\
27.7 \\
25.9 \\
24.6 \\
19.2\end{array}$ \\
\hline 2016-2017 & August-July & 6.6 & 61 & 16.6 & 14.1 & 54 & 34 \\
\hline
\end{tabular}




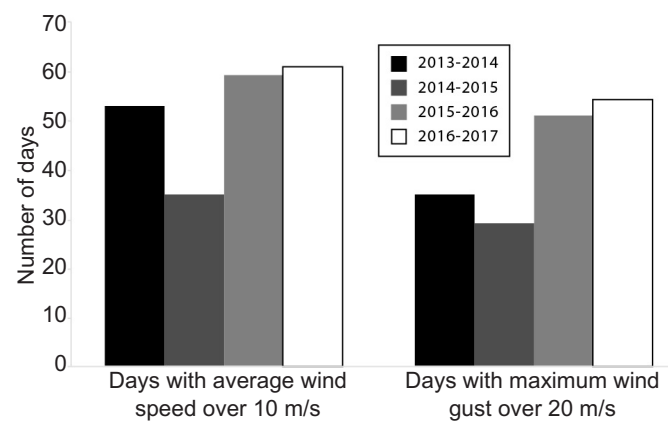

Fig. 6. Total number of days with an average wind speed over $10 \mathrm{~m} / \mathrm{s}$ (left) and maximum wind gust over $20 \mathrm{~m} / \mathrm{s}$ (right) for each year of this study.

There were also more windy days. The daily average wind speed was $6.6 \mathrm{~m} / \mathrm{s}$, with a daily average maximum of $14.1 \mathrm{~m} / \mathrm{s}$. The strongest winds blew from February to June, with the maximum monthly average wind speed of $8.5 \mathrm{~m} / \mathrm{s}$ in April. The annual maximum wind gust of $34 \mathrm{~m} / \mathrm{s}$ occurred in February and was the strongest recorded gust in all 4 years of this study.

\section{Descriptions of Site Erosion Processes}

The northern half of Santa Rosa Island (north of the east-to-west-trending, primarily strike-slip Santa Rosa Island fault) is mostly composed of an older marine terrace that has been dissected by stream networks, giving this half of the island a flat shape. Uplift on the north side of the fault has been slightly faster $(0.15 \mathrm{~m} / \mathrm{ka})$ than uplift on the south side of the fault $(0.12 \mathrm{~m} / \mathrm{ka}$; Muhs et al. 2014), but we consider these terraces comparable despite this small difference in uplift. A more significant difference is that the north coast of the island is in the direct line of wind and winter storm waves. Because of the onshore wind, much of this area is covered by sand dunes and sand sheets primarily made up of marinederived calcium carbonate $\left(\mathrm{CaCO}_{3}\right)$ sand. This sand is blown onshore from what is now the insular shelf around the island, which is exposed during sea level low stands. Evidence of soil development and plant colonization between older (middle Pleistocene) and newer (latest Pleistocene to early Holocene) sand deposits suggests that these dunes were stabilized by vegetation during a sea level high stand when this source of sand was underwater and therefore not blowing onshore (Muhs et al.
2009). The younger sand deposits are now mostly stabilized by vegetation, with the exception of a few active dune fields. Older sand deposits are cemented by calcium carbonate and have strength variations within reflecting depositional surfaces and rootcasts (Muhs et al. 2009, Schumann et al. 2014). Historic loss of vegetation from grazing, subsequent drought, and a few large storms likely allowed for rapid gully incision and wind erosion (deflation) into the sand layers below.

Northwest Coast (SOledad AND Dry CANYONS).-CA-SRI-19: Archaeological material at this site was deposited on a terrace that begins as a stream terrace within Soledad Canyon and grades into the 120-ka marine terrace (Fig. 7a). The terrace and overlying archaeological material are being eroded by sea cliff retreat at the coast and by gully incision into the terrace throughout the interior of the site (Table 3). The gullies are concentrated on the steep slopes (terrace risers) above and below the low-slope terrace surface. Some of the gullies above the terrace do not cross the terrace surface, where low slope gives flowing water less power to erode, but instead deposit sediment onto the terrace in fans. Other gullies connect from above the terrace to the sea below the terrace. A ranching-era road follows the terrace along Soledad Canyon to the sea here but is no longer drivable where gullies that connect across the terrace have incised tens of meters below the road elevation.

Schumann et al. (2016) describe recent incision of Soledad Creek into its bed, which would have caused base-level lowering of some of the gullies. These gullies do not connect through the terrace, however, while those that flow directly to the sea do cut all the way across the low-slope terrace surface. Therefore, we speculate that ranching activity, including animal grazing and an abandoned, washed-out road along the terrace here, has had a stronger influence on gully development than base-level lowering. Three horizontal retreat points on erosional faces were measured at this site, 1 on the sea cliff and 2 along gullies. All 3 erosion measurement points are directly exposed to wind off the ocean such that both precipitation and wind influence erosion at the locations of these measurements.

CA-SRI-821: This site is a small remnant of a marine terrace near the mouth of Dry Canyon (Fig. 7b). Because this terrace remnant 

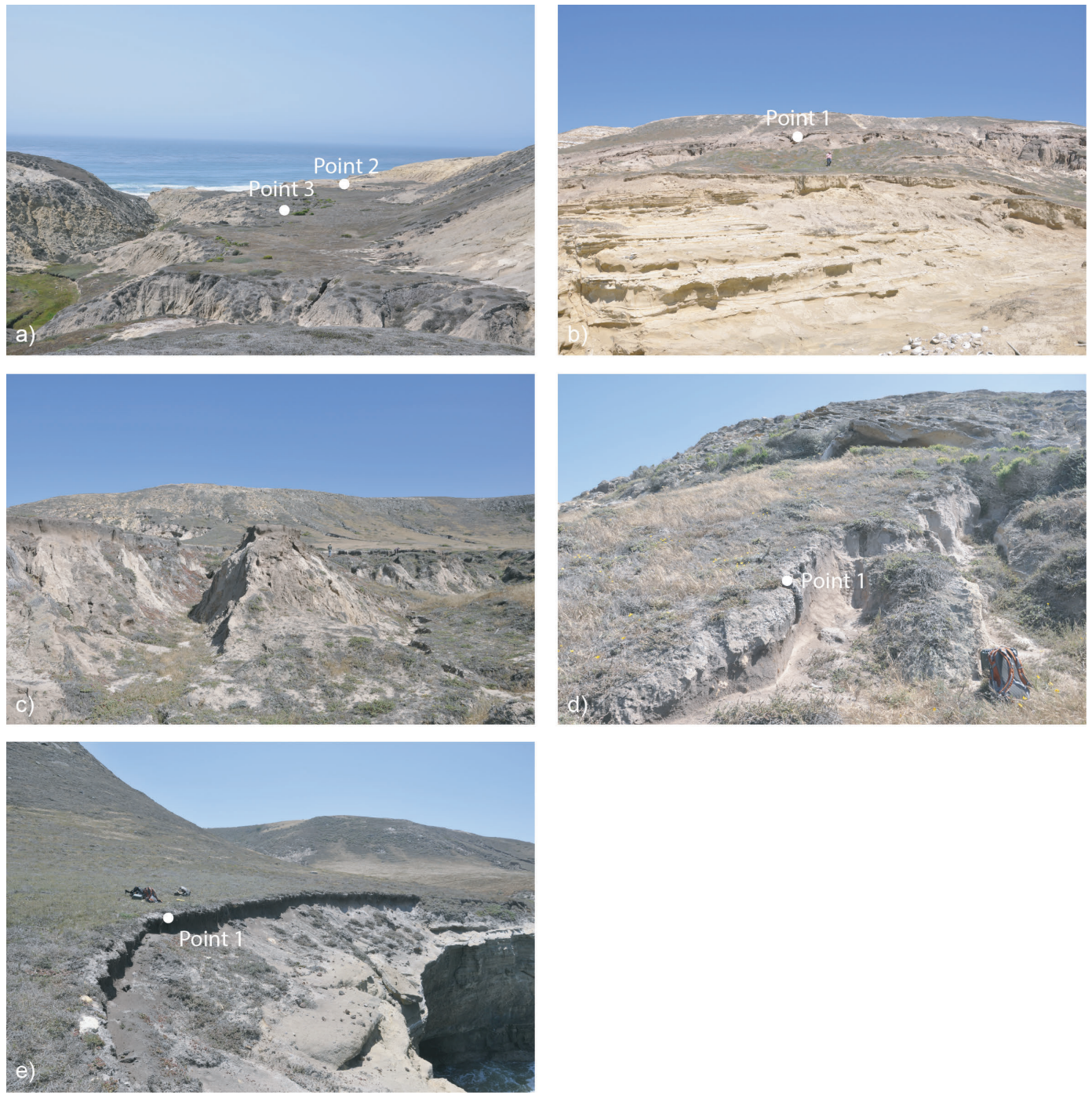

Fig. 7. Representative images of the types of erosion discussed in the text: (a) CA-SRI-19: Erosion from a road and gullies are thoroughly dissecting the site. The stream in Soledad Canyon is visible in the background; (b) CA-SRI-821: A scarp on a steep riser between 2 terraces is being eroded by wind and water; (c) CA-SRI-115: A midden lines the top of the gully edge and the dune in the center; (d) CA-SRI-541 and (e) CA-SRI-542: Wind-driven erosion of the terracecapping sand is outpacing erosion of the sandstone bedrock that is being undercut by wave action approximately $20 \mathrm{~m}$ below. Vegetation is holding soil and archaeological material intact.

protrudes into the ocean, waves erode the terrace fragment on both sides. The steep paleo sea cliff (inland of the terrace) is dramatically eroded by gullies that flow to either side of the low-slope terrace remnant. Wind-blown sand and colluvium deposited from the paleo sea cliff onto the terrace are interbedded with the cultural strata of the site and a soil has formed over them. The sea cliff retreat is progressing toward the cultural deposit, and soil erosion has exposed the cultural strata back from the sea cliff. The point at which horizontal retreat into a cultural deposit was measured is a steep slope between the edge of the scrap of terrace and the sea cliff. The area is steep and seems to be the terrace riser between the 2 youngest terraces. Surface features indicative of wind erosion (e.g., less erosion behind hard objects like shells [ventifacts]) suggest that wind is an important erosive agent here. Though the 


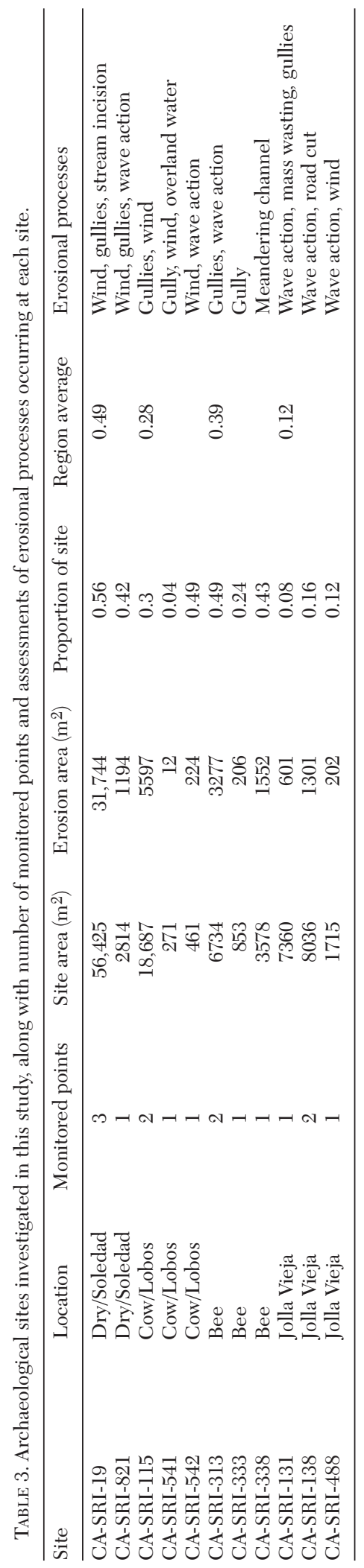

upstream area that funnels overland flow of water to this location is small, the steep slope gives water more potential to cause erosion. Therefore both precipitation and wind could influence erosion at this point measurement.

North Coast (COW \& Lobos Canyons).CA-SRI-115: This site is an old dune complex overlying the 120-ka marine terrace which has been stabilized by vegetation. Now a well-developed soil and lenses of calcium carbonate cementation within the sand add strength to the section. Cultural material is interbedded with eolian sand at the top part of the section (Fig. 7c). Waves erode the terrace bedrock at the seaward edge of the site, causing sea cliff retreat. An extensive gully network, likely coeval with ranching, dissects the interior of the terrace and flows directly into the ocean, not a stream channel. The steep slope behind the terrace is extensively gullied; some of these gullies continue across the low-slope terrace while others deposit sediment in fans onto the terrace surface. The gully network studied here cuts into the low-slope surface and connects to the sea. However, the base of the gully network is perched at the terrace bedrock contact, incising only dune and terrace-capping sand. Therefore, the gully hangs above sea level. This hanging gully is another indication that gully formation resulted from a loss of vegetation and surface strength rather than erosion propagating upstream from a change in base level. Gully walls are now being stabilized by vegetation, but seaward exposures of the terrace/dune complex are less vegetated, allowing wind to accelerate erosion (Fig. 7c). Erosion was measured at this site in 2 places: 1 point along the sea cliff and 1 point at the bank of the main gully. Wave action and wind have a high potential to control erosion at the coastal point. The gully wall is fully exposed to wind off the ocean, so wind, vegetation, and gully flow all have the potential to cause erosion of the cultural layer in the gully bank.

CA-SRI-541: This site is similar to CA-SRI115 but is located at the back of the terrace on the steep terrace riser. Soil is developed on a thin layer of colluvium overlying bedrock (Fig. 7d). Cultural deposits are within the colluvium. A gully has incised through the colluvium and into the bedrock. The erosion measurement point is along the bank of this gully. The flow of water in the gully is 
responsible for the erosion of the site, but direct exposure to wind off the ocean may also play a role.

CA-SRI-542: This site is the edge of a marine terrace with eolian sand capping midden deposits overlying the terrace-capping sand. The surface is stabilized by vegetation and a well-developed soil (Fig. 7e), but terrace rock is being eroded by wave action below. While site erosion is typical of sea cliff retreat, erosion of the sediment and cultural material overlying the terrace bedrock is outpacing erosion of the bedrock shelf. Punctuated failure of the sea cliff from wave action below is likely the long-term driver of erosion. However, erosion of terrace-capping sediment and cultural material was measured here, not the retreat of the bedrock sea cliff. A bedrock bench remained between the retreating scarp and the sea cliff during the 4 years of measurement. When the bedrock fails, the overlying sediment and cultural material will erode as well, but the erosion represented in these data was from wind and precipitation acting on the soft sediment, not bedrock cliff failure from undercutting wave action.

Southwest Coast (Bee Canyon).--Sites on this coast are located on a wide marine terrace that is backed by the higher topography south of the Santa Rosa fault. This part of the 120-ka marine terrace has less aeolian sand because the dominant wind direction is parallel to the coast. There is extensive loss of soil and shallow dense channel erosion (rills) on the steep paleo sea cliff at the back of the terrace (terrace riser), likely resulting from historic grazing and loss of surface strength. In many places, the shallow dense channels above the terrace do not erode into the terrace but instead deposit eroded material on the surface where low slope reduces the sediment transport capacity of flowing water. In some cases, however, channels coalesce and do incise into the marine terrace. A dirt road may have accentuated the erosion caused by some of these through-going channels by concentrating the overland flow of water.

CA-SRI-333: This site is along one of the gullies that begins on the steep paleo sea cliff (Fig. 8a). The gully has caused shallow erosion into the terrace-capping sediment and cultural material upslope from an old road, but the gully does not continue below the road all the way to the coast. Water from this gully seems to pool on the terrace below the road, and a fan of sediment has been deposited there. When water flows in the gully, some may flow across the terrace and contribute to erosion elsewhere and some may flow along the old road, but there is no single gully connecting to the edge of the terrace. This evidence suggests that gully erosion may have started at the road and propagated upstream and that flatter areas below the road were not steep enough to continue the transport of sediment to the edge of the terrace. Vegetation and sediment deposition within this gully suggest that it is no longer deepening, but erosion measured at the top of the gully bank indicates that the channel is still widening. The vertical banks suggest that this erosion is caused by water undercutting the bank and subsequent bank collapse. No evidence of wind erosion was observed.

CA-SRI-313: This area is a topographic low collecting water from many gullies which deposit sediment on the terrace (Fig. 8b). The accumulated water and the steep slope of the terrace's sea cliff edge has caused gully erosion a short way back into the terrace surface here. Sea cliffs undercut by wave action may be keeping the sea cliff steep and accelerating gully erosion. One gully grades smoothly to sea level while others are hung up on terrace bedrock, causing waterfalls at the coast when the gullies flow. Erosion was measured in 2 places where sea cliff retreat and gully bank retreat are working together at corners where gullies meet the coast. Both precipitation and wind influence erosion at these points.

CA-SRI-338: Cultural material at this site is exposed in the canyon wall of Bee Canyon, a major drainage that crosses the marine terrace. This material is above terrace-capping sand and below soil and vegetation. Lateral migration (meandering) of the modern channel of Bee Canyon controls erosion of the canyon walls (Fig. 8c). Along most of this site, the active channel has moved away from the canyon wall because of a meander cutoff and is therefore no longer undercutting the bank. Despite removal of the initial cause of erosion, the bank is still too steep to be stable, and it continues to erode laterally at the point measured, creating a gentler slope. The spread of vegetation continues to further stabilization. The overland flow of water is likely a more important cause of erosion here than wind, 

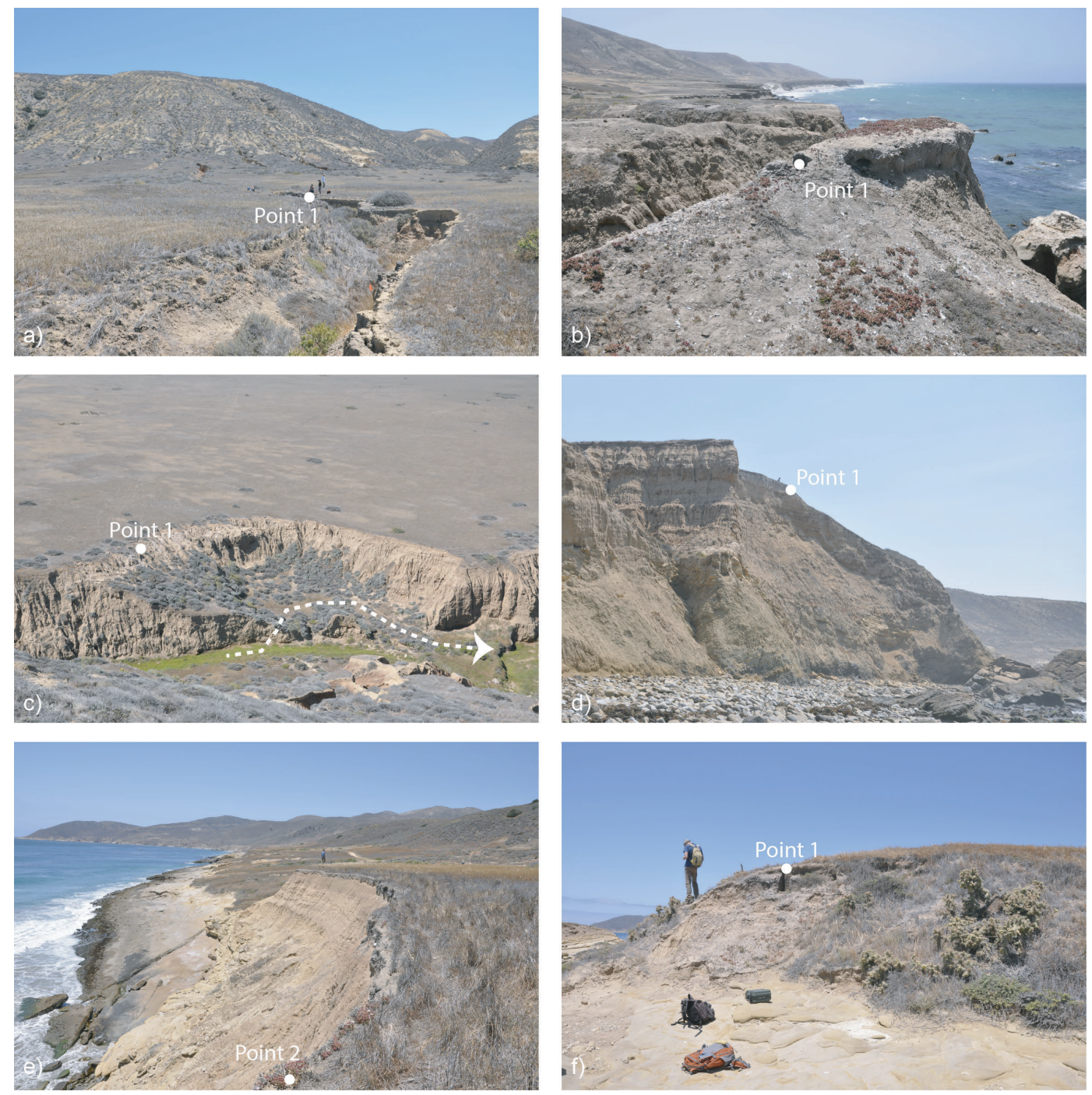

Fig. 8. Representative images of the types of erosion discussed in the text: (a) CA-SRI-333: A shallow gully cutting into the marine terrace; (b) CA-SRI-313: Remnants of a marine terrace dissected by gullies and eroding at the coast; (c) CA-SRI-338: The active channel of lower Bee Canyon formerly undercut this steep stream bank (see dotted arrow). Subsequent lateral migration and cutoff of a meander bend has moved the active channel away from this bank, leaving terraces at 2 elevations. A block of bedrock remains around which the stream used to flow; (d) CA-SRI-131: A steep sea cliff (approximately $30 \mathrm{~m}$ high) stands here. Cliff retreat is primarily caused by collapse of the whole terrace face, including weak bedrock and cap; (e) CA-SRI-138: Another example of sea cliff retreat, this time dominated by wave action below, with a collapse of the whole face; (f) CA-SRI-488: Another sea cliff at the marine terrace edge being eroded by waves below. In this close-up of the top edge of the terrace, the bedrock contact is exposed where other forces, likely dominated by wind erosion, have removed the terrace-capping sediment.

because the site is set back from the coast and somewhat protected from the wind, but wind may still play a role.

South Coast (La Jolla Vieja).- - This area is in the lee of prevailing wind and waves, and for these reasons probably had less deposition of eolian sand on the terrace during sea level low stands than other parts of the island (discussed earlier). Cultural materials were deposited on the terrace surface and are exposed most prominently along sea cliffs where a cross section of the terrace is exposed. An exception is a road cut at CA-SRI-138 which exposed thick $(77-\mathrm{cm})$ midden deposits. 
CA-SRI-131: Classic sea cliff retreat into a terrace is occurring at this site, exposing cultural material above the terrace deposit and below soil. Erosion was measured at the cliff edge (Fig. 8d).

CA-SRI-138: This site is experiencing classic sea cliff erosion into a marine terrace (Fig. 8e). Erosion was measured at one point along the sea cliff where cultural material is exposed above the terrace deposit and below soil and vegetation, and at a second point back from the sea cliff along a road cut that exposes cultural material and terrace-capping sediment below.

CA-SRI-488: This site is a marine terrace experiencing classic sea cliff retreat by wave action and wind (Fig. 8f). Erosion was measured at the cliff edge.

\section{Horizontal Bank Retreat Measurements}

Annual measurements of the retreat of gully sidewalls and sea cliffs provide a way to track annual erosion of cultural deposits (Table 4, Fig. 9). We calculated the retreat of each site over the 4-year study and examined the differences between gully and sea cliff retreat and between windward and leeward coasts. The greatest erosion in one year was $16 \mathrm{~cm}$ of gully wall retreat at CA-SRI-115. The highest average erosion in an area occurred at the mouth of Dry/Soledad Canyons along the windward northwest coast of the island (average total erosion of $13.75 \mathrm{~cm}$ per monitoring point over the 4 water years). The least erosion occurred at the mouth of Bee Canyon (average total erosion of $4.5 \mathrm{~cm}$ per monitoring point total over the 4 water years), which is protected from northwesterly storms by Sandy Point and the west end of the island. Cow/Lobos Canyons, which are protected somewhat from northwesterly storms by Brockway Point, had the second most evidence for erosion (8 $\mathrm{cm}$ per point). La Jolla Vieja Canyon on the lee side of the island experienced an average of $6.25 \mathrm{~cm}$ of total erosion per monitoring point. These relative values are consistent with the orientation of these areas to weather patterns on the islands, with the most erosion on the northern side. However, annual erosion measurements do not fit this pattern as cleanly because of some variation in weather conditions and location of the sites on the island.
Annual erosion was lowest in 2013-2014 except at Cow/Lobos Canyons where gully sidewalls and sea cliffs retreated more than in subsequent years. This was largely the product of a single measurement taken at Point 1 of CA-SRI-115 where $16 \mathrm{~cm}$ of the wall had retreated. This brought the average for Cow/Lobos Canyons to $4.75 \mathrm{~cm}$ per point. No other location averaged more than $1 \mathrm{~cm}$ that year. While there appears to have been relatively low erosion overall in 2013-2014, the gully erosion at CA-SRI-115 represents punctuated loss of cultural material, with much of the eroded cultural material visible in the gully below.

In 2014-2015, annual erosion increased at all 4 locations on the island except Cow/Lobos Canyons. This is evident in the average amount of erosion at Dry/Soledad Canyons $(3.5 \mathrm{~cm})$, Bee Canyon $(2.5 \mathrm{~cm})$, and La Jolla Vieja Canyon $(1.25 \mathrm{~cm})$. By the end of the year, all 4 points at the mouth of Dry/Soledad Canyons had experienced at least $3 \mathrm{~cm}$ of erosion, as did 3 of the 4 points at the mouth of Cow/Lobos Canyons. In 2015 we observed evidence of undercutting at several of these points. Undercutting is most extreme at Dry/Soledad Canyons and Cow/Lobos Canyons, further accentuating the greater erosion there than at Bee Canyon and La Jolla Vieja Canyon. Qualitative observations of erosion around the monitored points also support the assertion that overall erosion on Santa Rosa Island increased in 2014-2015 and that erosion was greatest at Dry/Soledad Canyons.

There was a decrease in annual erosion in 2015-2016 in all locations except Dry/Soledad Canyons $(4.5 \mathrm{~cm})$. Erosion was intermediate at Bee Canyon $(1.75 \mathrm{~cm})$ and equivalent to 2013-2014 at La Jolla Vieja Canyon $(1 \mathrm{~cm})$. There was also a decrease at Cow/Lobos Canyons $(1.5 \mathrm{~cm})$, which was the lowest overall value for that location in this study. We observed evidence of undercutting in the gully sidewalls and sea cliffs on the less protected northwest and north coasts of the island at the same locations it was visible in 2015. Furthermore, our qualitative assessment of annual erosion reflects continued erosion across the island, with only one point (CA-SRI-313, Point 2) still $100 \mathrm{~cm}$ from the eroding sea cliff. Sediment has hardened there, so we expect a pattern of punctuated loss from wave action. 


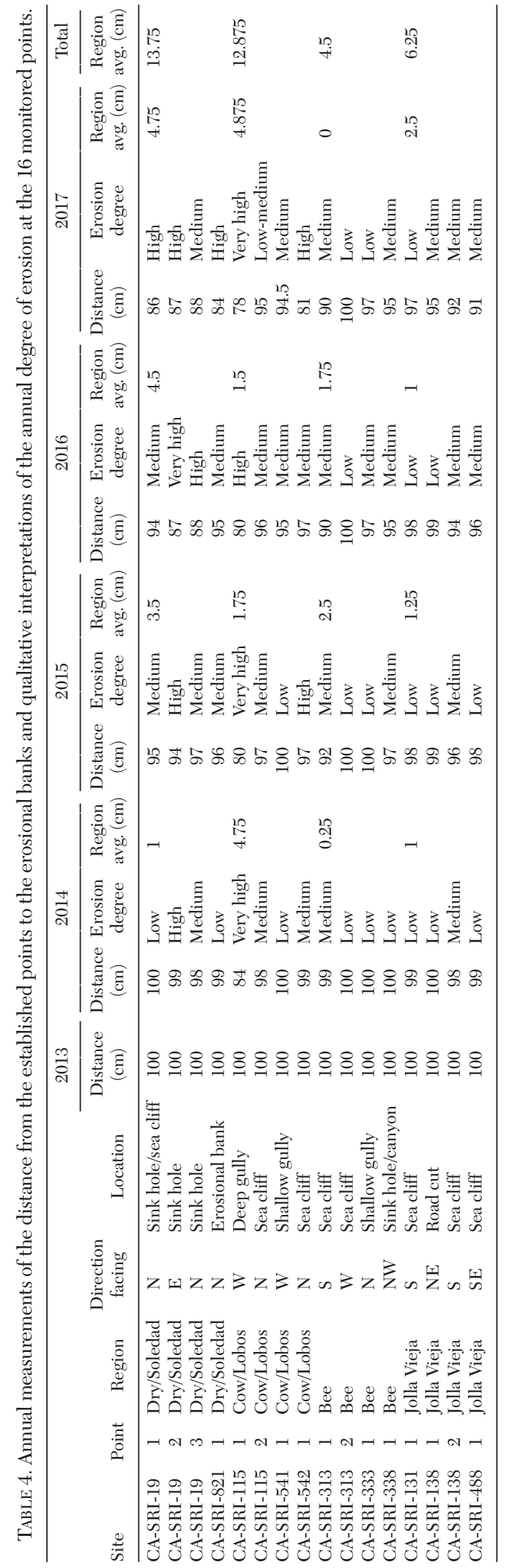

The 2016-2017 water year had the highest annual precipitation and wind. Higher total erosion was measured at all locations except Bee Canyon in this year (Fig. 9). However, sea cliff retreat contributed most of this erosion, and erosion at gulley points was at its lowest this year. Annual erosion at Dry/Soledad Canyons $(4.75 \mathrm{~cm})$ and Cow/Lobos Canyons $(4.875 \mathrm{~cm})$ was at its highest levels of the 4 years and represented the greatest annual erosion recorded during the study. La Jolla Vieja Canyon $(2.5 \mathrm{~cm})$ also experienced more erosion in this year than in previous years. There was no evidence of erosion at Bee Canyon (CA-SRI-313, Point 2) nor points $0.5 \mathrm{~km}$ or more from the coast (CA-SRI-333 and CASRI-338).

\section{Discussion}

This study indicates that annual erosion patterns of archaeological sites are strongly related to the intensity of winter weather, the location of sites on the island with respect to prevailing winds and storms, and the geomorphic processes responsible for erosion at each site (e.g., sea cliff retreat, gully bank retreat). Sites along the north coast of the island are the most exposed to northwesterly storms and other weather patterns. These sites, therefore, experienced greater erosion over the course of this study, and are more eroded overall than sites along the south and west coasts. All sites directly along the coast have some evidence of sea cliff retreat, but fluvial and eolian erosion appear to be most pronounced along the northwest coast of the island. Jazwa (2017) has argued that the age of sites appears to be less important for their preservation than their location, emphasizing the role of historic grazing and devegetation and ongoing geomorphic processes like sea cliff retreat in destabilizing sediments and contributing to much of the erosion influencing archaeological sites today. Our observations of the restabilization of sediments in and adjacent to gullies since grazing animals were removed by CHIS reinforces this interpretation.

There is a clear relationship between the amount of rainfall during winter storms and the measured annual erosion at archaeological sites. Of the 4 years in this study, 2016-2017 was the rainiest overall by over $140 \mathrm{~mm}$ and had the strongest storms. It was also the 


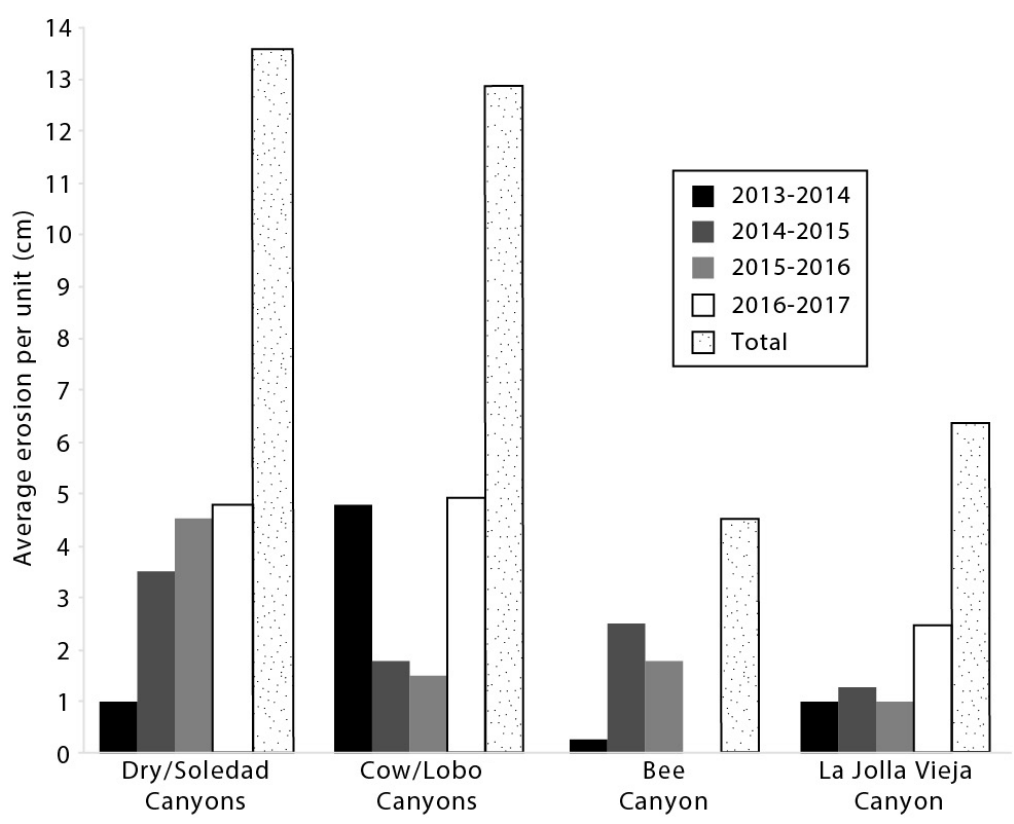

Fig. 9. Average loss of sediment from the eroding banks at each of the geographic locations investigated. Erosion measurements are presented for the individual years of this study along with the 4-year totals (2013-2017).

windiest year in terms of total number of windy days and a close second in terms of average wind speed and wind gust.

The year 2014-2015 was the second rainiest overall. December 2014 was the rainiest month in the study, with more rain falling that month than in all of 2013-2014 and 90\% of the total rain that fell in 2015-2016. The largest rain events that month occurred during storms that were coincident with heavy winds. The largest storm was on 2 December $2014(89.2$ $\mathrm{mm}$ of rain), which had wind gusts of $20.1 \mathrm{~m} / \mathrm{s}$ and an average wind speed of $9.3 \mathrm{~m} / \mathrm{s}$. Other storms on 11, 12, 15, and 16 December were also associated with high winds. Average erosion at all measured archaeological sites was also greatest for the 4 years of this study in 2014-2015 (a mean of $2.25 \mathrm{~cm}$ per measurement point that year). In terms of specific regions, Bee Canyon's maximum erosion occurred in 2015, and Jolla Vieja Canyon and 3 of the 4 points measured at Cow/Lobos Canyons experienced their second-highest annual erosion in 2015. Dry/Soledad Canyons also experienced an increase in erosion from the previous year.

The 2015-2016 winter was during a strong El Niño with anomalies in sea surface temperature among the highest in recorded history
(NASA 2015, NOAA 2016a, 2016b). Despite the strength of the 2015-2016 El Niño, it was intermediate in terms of total rainfall. However, more rainy days occurred in 2015-2016 than in previous years. These days primarily had light rain rather than storms, contrary to what would be expected during an El Niño. Still, 2015-2016 was the windiest year in terms of average daily wind speed and maximum wind gust. Erosion overall was third $(2.19 \mathrm{~cm}$ per measurement point). The one region that had a greater amount of erosion in 2015-2016 than during the previous winter was Dry/ Soledad Canyons, which is directly in the path of northwesterly storms and winds. In this year we observed less erosion in the Cow/Lobos area than in other study years and intermediate erosion in Bee and Ja Jolla Vieja Canyons.

In our study period, 2013-2014 had the lowest total precipitation and fewest rainy days of all the years monitored in this study. Measurements of annual erosion are consistent with this. In all locations except Cow/Lobos Canyons, annual erosion was lowest during 2013-2014. At Cow/Lobos Canyons, the higher average erosion was driven by a single point (1) at CASRI-115 $(16 \mathrm{~cm})$. When considering the other 3 points in this region, trends in annual erosion are consistent with the other areas. 
Sea Cliff Erosion (8 Points)

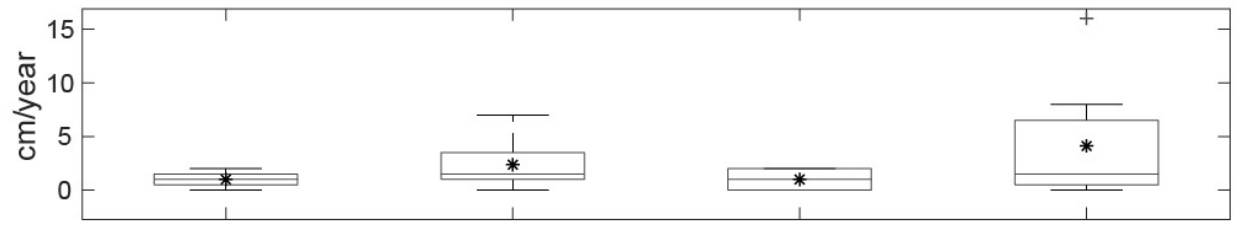

(a)

Gully Erosion (6 Points)

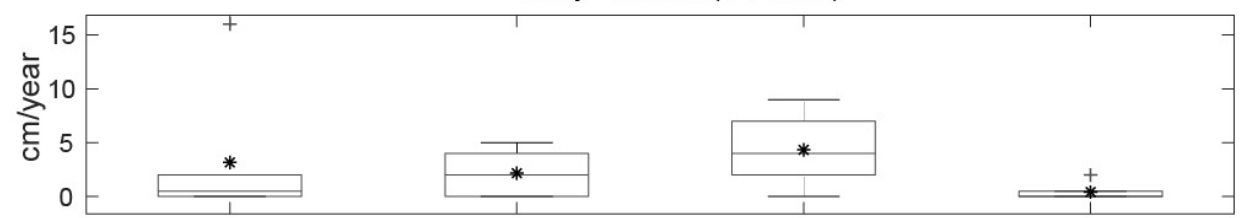

(b)

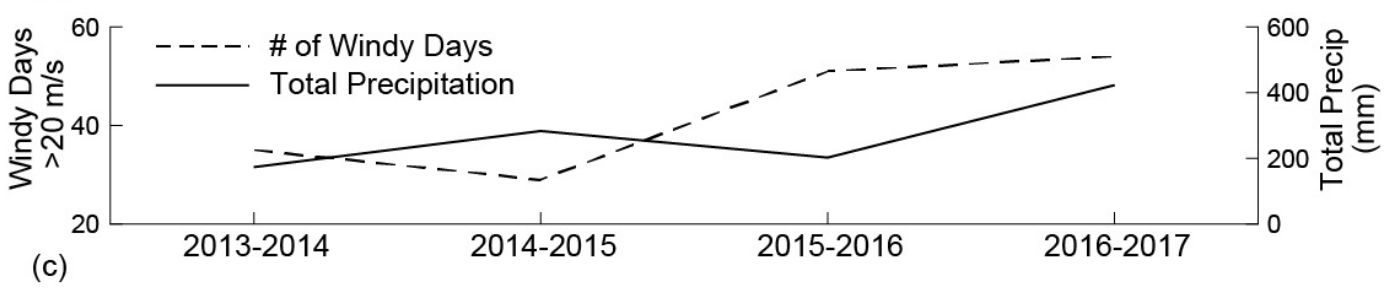

Fig. 10. Sea cliff erosion (a) versus erosion along gully banks (b) per year plotted with wind and precipitation data (c). Measurements from CA-SRI-138 (road cut) and CA-SRI-821 (terrace riser) were excluded, so each plot represents a single erosional process, either sea cliff retreat or gully wall retreat. In general, sea cliff erosion correlates best with precipitation likely because of storm waves and wet cliff material. Gully widening was highest in a low precipitation year (2015-2016) and lowest in the highest precipitation year (2016-2017). We suggest that this phenomenon results from early rain and growth of annual grasses in 2016-2017 that reduced erosion in subsequent storms and lack of this protection during the late-winter storms of the otherwise dry 2015-2016 winter. Box edges indicate 25th and 75th percentiles of data. Medians are denoted with a line within the box. Whiskers show the full range of data, excluding outliers which are indicated with a plus symbol $(+)$. Means are indicated with an asterisk $(*)$.

Correlation of Horizontal Bank Retreat Measurements with Process and Location

Regional variations in annual erosion across Santa Rosa Island show a relationship with the orientation of sites to prevailing northwesterly weather patterns (Fig. 9). Overall, erosion on the windward side of the island was greater than erosion elsewhere. The windward northwestern sites at the mouth of Dry/Soledad Canyons experienced more annual erosion than sites at Bee Canyon on the west coast, which are protected by Sandy Point and the west end of the island, and those near La Jolla Vieja Canyon on the leeward southern coast of the island, which is protected by the main ridgeline of Soledad Peak.

Sea cliff retreat in general varied more by coastal aspect than did gully bank retreat and also showed more of a correlation with annual total precipitation and other precipitation metrics than did gully sidewall retreat rates which, surprisingly, did not show much correlation with total precipitation. The correlations between rates of sea cliff retreat and precipitation and between rates of sea cliff retreat and coastal aspect are both perhaps because of a correlation between winter storms, precipitation, and waves rather than a direct influence of precipitation on sea cliff retreat, but further study is needed to make these causative links. Saturation of the sea cliff may also influence cliff stability (Griggs et al. 2005). Sea cliff retreat is known to be punctuated, so the measurements from our short observation period are bound to differ from long-term patterns (Griggs et al. 2005). Future work, including an exploration of wave energy correlations, would aid predictions of cliff retreat on Santa Rosa Island. Griggs et al. (2005) explored controls on sea cliff retreat in detail along the entire mainland coast of California. The 
Channel Islands were not included in that study, but our data suggest that such a detailed study of sea cliff erosion on the islands would greatly benefit the management of cultural resources on these islands.

Somewhat surprisingly, gully bank retreat did not correlate well with precipitation metrics. A stronger predictor of gully bank retreat was coastal aspect, with windward gullies showing more erosion than leeward gullies (Fig. 10). Although the process of gully sidewall retreat is controlled by overland flow of water and undercutting of the gully sidewalls by water flowing in the gully channel, these results suggest that this is not the whole story. Gully incision and soil loss became widespread across the NCI as a result of ranching. It is widely believed that the loss of vegetation is a primary cause of gully initiation because erosion by flowing water is influenced by the strength of the material being eroded. Vegetation has a strong control on surface strength, as shown on the NCI, with the correlation in time between grazing and the initial formation of gullies (Brumbaugh 1980, Brumbaugh et al. 1982, Perroy et al. 2012). Precipitation patterns influence vegetation and the amount and strength of flowing water, with lighter rain giving plants such as annual grasses a chance to stabilize gully edges. Our data show more gully erosion during the 2 drier years than the 2 wet years, which suggests that the drought's influence on vegetation could have enabled overland flow to lead to more erosion despite less total precipitation.

For example, despite the El Niño, 2015-2016 was a very dry year during a multiyear drought in California. There was observably less annual grass growth that year than in 2016-2017. These multiyear patterns in precipitation should be considered along with annual precipitation. The data show more erosion at windward gully sites than leeward sites during these dry years. Wind will dry out moist soil faster, limiting vegetation growth. Strong wind can also mechanically suppress plant growth. With other confounding variables, however, it is not clear whether this causes the difference between windward and leeward gully erosion. Some evidence was seen of direct wind erosion on scarps that were initially eroded by water flowing in gullies (e.g., ventifacts at CA-SRI821 ), but this is likely a secondary process because gully bank erosion is primarily con- trolled by flowing water. We suggest that more work focusing on the influence of wind on soil moisture and plant growth could help explain why wind patterns seem to correlate with erosion at gully banks. Many of the sites have old ranch roads intersecting gullies. The role of these roads in routing flow to gullies was not controlled for in this study but is likely another influencing factor worthy of study.

Limitations, Future Study, and Implications for Site Management

Monitoring erosion at archaeological sites is a long-term goal and should play an important role in managing cultural resources. This study provides an overview of the response of sites undergoing different types of erosion to different environmental conditions. The most prominent limitation of this study is the length of the measurement record and the frequency of data collection. It was not practical for our purposes to collect data on the erosion occurring at these archaeological sites more often than once per year, so we cannot be certain that erosion occurred during individual prominent storms. Instead, we can only look at patterns from year to year. More frequent measurements would make it possible to determine the relationship between individual storms and punctuated erosion. Similarly, data were collected from a relatively limited number of monitoring points. Variation in erosion patterns would be detected more completely with a larger number of points from a greater number of sites. In addition, having weather station data and wave energy data from more locations around the island would enable more quantitative interpretations of the role of weather patterns on sites.

Our work is generally consistent with recent studies using coastal vulnerability indices calculated for California broadly (Thieler and Hammar-Klose 2000) and Santa Barbara County specifically (Pendleton et al. 2005, Reeder et al. 2012). These values range from 1 (very low vulnerability) to 5 (very high vulnerability). They were calculated based on geomorphology, historical rates of shoreline change, coastal slope, relative sea level rise, wave action, and tidal range. The broad-scale analysis by Thieler and Hammar-Klose (2000) places the vulnerability of the north and west coasts of Santa Rosa Island at very high vulnerability and the south coast at high vulnerability. This is consistent with our findings, 
with the exception of the west coast. A more detailed study by Reeder et al. (2012) places Dry/Soledad and Cow/Lobos Canyons sites in the range of medium-high vulnerability, La Jolla Vieja Canyon sites at medium vulnerability, and Bee Canyon sites at medium vulnerability, except at Bee Point (very high vulnerability) where CA-SRI-313 is located. Because the sites all appear to be at roughly the same risk level, it makes the indices difficult to compare to our findings.

We intend to continue monitoring erosion at these sites to determine long-term responses of site preservation to annual fluctuations in weather, climate change, and vegetation recovery. This study will also benefit from an expansion that will include more points per site and more sites around Santa Rosa Island. The data presented here demonstrate that erosion is not consistent around the NCI and that special attention should be paid to sites that are most prone to being lost. Currently when archaeological surveys are performed, one of the observations noted in the site record is "site condition," a nebulous designation that includes factors that threaten site preservation. When considering the condition of archaeological sites, it would be valuable to distinguish the types of erosion occurring at the site and the risk of future erosion. Archaeological sites on the NCI benefit from relatively little development compared to the mainland and the removal of grazing animals, but sites are nonetheless at risk of erosion. A combination of risk of data loss and the potential for addressing research questions should be considered when excavating sites, which has been done to some degree (Kennett 2005, Jazwa 2015). Collaboration between geomorphologists and archaeologists can guide future excavations that can be mutually beneficial for furthering our knowledge of and maximizing site preservation.

\section{Conclusion}

This study explores the relationships between geomorphic processes, the weather patterns that influence them, and the erosion of archaeological sites on Santa Rosa Island. We have shown that during 4 consecutive winter rainy seasons, precipitation and wind were related to the amount of erosion occurring at coastal archaeological sites. The year with the most rain and the greatest number of rainy days, 2016-2017, was the year with the highest average erosion around the island. The 20142015 year also had a large amount of rain and many storms, particularly in December 2014, causing the second highest average erosion. The 2015-2016 strong El Niño year averaged an intermediate amount of rain and erosion. The driest year, 2013-2014, had the lowest average site erosion. Over the 4-year study, the most erosion occurred at the mouth of Dry/Soledad Canyons, which is directly in the path of northwesterly weather. The least erosion occurred at Bee Canyon along the protected leeward coast. Cow/Lobos Canyons and La Jolla Vieja Canyon experienced intermediate rates of erosion. Data suggest that winter storms are the greatest cause of sea cliff retreat, with windward sea cliffs eroding more than leeward sea cliffs and more erosion occurring in stormier years. Gully erosion was also greatest on the windward side of the island, but erosion rates of gully walls were greater in years with less precipitation. This may be because soil moisture promotes stabilization by vegetation (such as annual grasses) in wetter years at sites with less wind to dry the soil. Further study is required to more fully understand these patterns.

This study incorporates geomorphological and archaeological data to better understand erosional processes within anthropogenically modified landscapes and to predict the loss of archaeological sites. The NCI have long been recognized for the important data that they provide for addressing some of the most pressing contemporary topics in archaeology, like the emergence of sociopolitical complexity and the route of colonization of the Americas (Arnold 1992, Kennett 2005, Erlandson et al. 2011). The results of this study and the ongoing monitoring of site erosion can maximize the data collected from the NCI by both preserving valuable cultural resources and determining which sites should be excavated to mitigate data loss from erosion. Methods incorporating geomorphic contexts such as those developed here can be applied to other locations along the world's coastlines to understand archaeological site erosion and aid in the management of cultural resources.

\section{ACKNOWLEDGMENTS}

We thank Channel Islands National Park, Kelly Minas, Laura Kirn, Don Morris, and 
Ann Huston for help with this study. This research was supported by Channel Islands National Park (Jazwa; 135414, P11AC30805), the National Science Foundation (Jazwa; BCS-1338350 and BCS-1623514), Pennsylvania State University, and the University of Nevada, Reno. Sarah Mellinger, Kyle Garcia, Michelle Wilcox, Amber Marie Madrid, Terry Joslin, Blaize Uva, Hugh Radde, Stephen Hennek, Nathan Beckett, Henry Chodsky, Michael Price, Kyle Jazwa, Scott Sunell, Annamarie Leon Guerrero, and Richard-Patrick Cromwell assisted with fieldwork. We would also like to thank Michael Glassow, Dan Muhs, and an anonymous reviewer for thorough review which improved this manuscript. This collaboration began at the 9th California Islands Symposium and includes contributions from each of our presentations, exemplifying the benefits of interdisciplinary conferences.

\section{Literature Cited}

Adams, P.N., R.S. Anderson, and J. Revenaugh. 2002. Microseismic measurement of wave-energy delivery to a rocky coast. Geology 30:895-898.

Agenbroad, L.D., J.R. Johnson, D. Morris, and T.W. StAFFord JR. 2005. Mammoths and humans as late Pleistocene contemporaries on Santa Rosa Island. Pages 3-7 in D.K. Barcelon and C.A. Schwemm, editors, Proceedings of the Sixth California Islands Symposium. Institute for Wildlife Studies, Arcata, CA.

Ames, K.M. 1994. The northwest coast: complex huntergatherers, ecology, and social evolution. Annual Review of Anthropology 23:209-229.

ANDERSON, R.S. 1986. Erosion profiles due to particles entrained by wind: application of an eolian sedimenttransport model. Geological Society of America Bulletin 97:1270-1278.

ARNOLD, J.E. 1992. Complex hunter-gatherer-fishers of prehistoric California: chiefs, specialists, and maritime adaptations of the Channel Islands. American Antiquity 57:60-84.

ARNOLD, J.E. 1995. Transportation innovation and social complexity among maritime hunter-gatherer societies. American Anthropologist 97:733-747.

ARNOLD, J.E. 1997. Bigger boats, crowded creekbanks: environmental stresses in perspective. American Antiquity 62:337-339.

ARnold, J.E. 2001a. The Chumash in world and regional perspectives. Pages 1-20 in J.E. Arnold, editor, The origins of a Pacific coast chiefdom: the Chumash of the Channel Islands. University of Utah Press, Salt Lake City, UT.

ARNOLD, J.E. 2001b. Social evolution and the political economy in the northern Channel Islands. Pages 287-296 in J.E. Arnold, editor, The origins of a Pacific coast chiefdom: the Chumash of the Channel Islands. University of Utah Press, Salt Lake City, UT.

Arnold, J.E., AND A.P. Graesch. 2004. The later evolution of the Island Chumash. Pages 1-16 in J.E.
Arnold, editor, Foundations of Chumash complexity. Cotsen Institute of Archaeology, Los Angeles, CA.

Arnold, J.E., S. Sunell, B.T. Nigra, K.J. Bishop, T. JONES, AND J. BONGERS. 2016. Entrenched disbelief: complex hunter-gatherers and the case for inclusive cultural evolutionary thinking. Journal of Archaeological Method and Theory 23:448-499.

Bailey, G.N., N.C. Flemming, G.C.P. King, K. Lambeck, G. Momber, L.J. Moran, A. Al-Sharekh, and C. VITA-FINZI. 2007. Coastlines, submerged landscapes, and human evolution: the Red Sea Basin and the Farasan Islands. Journal of Island and Coastal Archaeology 2:127-160.

BIRD, M.K. 1992. The impact of tropical cyclones on the archaeological record: an Australian example. Archaeology in Oceania 27:75-86.

Braje, T.J., J.M. Erlandson, and T.C. Rick. 2013. Points in space and time: the distribution of paleocoastal points and crescents on the northern Channel Islands. Pages 26-39 in C.S. Jazwa and J.E. Perry, editors, California's Channel Islands: the archaeology of human-environment interactions. University of Utah Press, Salt Lake City, UT.

Breen, C., AND P.J. Lane. 2004. Archaeological approaches to East Africa's changing seascapes. World Archaeology 35:469-489.

Brumbaugh, R.W. 1980. Recent geomorphic and vegetal dynamics on Santa Cruz Island, California. Pages 139-158 in D. Power, editor, A multidisciplinary symposium on the California islands. Santa Barbara Museum of Natural History, Santa Barbara, CA.

Brumbaugh, R.W., W.H. Renwick, and L.L. Loeher. 1982. Effects of vegetation change on shallow landsliding: Santa Cruz Island, California. General Technical Report PSW-58, Pacific Southwest Forest and Range Experiment Station, Forest Service, Berkeley, CA.

Cannon, A., AND D.Y. Yang. 2006. Early storage and sedentism on the Pacific northwest coast: ancient DNA analysis of salmon remains from Namu, British Columbia. American Antiquity 71:123-140.

Casey, R.E., A.L. Weinheimer, and C.O. Nelson. 1989. California El Niños and related changes of the California current system from recent and fossil radiolarian records. Geophysical Monograph 55:85-92.

Сobb, K.M., C.D. Charles, H. Cheng, and R.L. EDWARDS. 2003. El Niño/Southern Oscillation and tropical Pacific climate during the last millennium. Nature 424:271-276.

Daire, M.Y., E. Lopez-Romero, J.N. Proust, H. RegNaUld, S. Pian, And B. Shi. 2012. Coastal changes and cultural heritage (1): assessment of the vulnerability of the coastal heritage in western France. Journal of Island and Coastal Archaeology 7:168-182.

ErLandson, J.M. 1994. Early hunter-gatherers of the California coast. Plenum Press, New York, NY.

ERLANDSON, J.M. 2001. The archaeology of aquatic adaptations: paradigms for a new millennium. Journal of Archaeological Research 9:287-350.

ErLANDSON, J.M. 2002. Anatomically modern humans, maritime adaptations, and the peopling of the New World. Pages 59-92 in N. Jablonski, editor, The first Americans: the Pleistocene colonization of the New World. Memoirs of the California Academy of Sciences, San Francisco, CA.

Erlandson, J.M., D.J. Kennett, B.L. Ingram, D.A. Guthrie, D.P. Morris, M.A. Tveskov, G.J. West, 
AND P.L. WALKER. 1996. An archaeological and paleontological chronology for Daisy Cave (CA-SMI261), San Miguel Island, California. Radiocarbon 38:355-373.

Erlandson, J.M., T.C. Rick, T.J. Braje, M. Casperson, B. Culleton, B. Fulfrost, T. Garcia, D.A. Guthrie, N. Jew, D.J. Kennett, et AL. 2011. Paleoindian seafaring, maritime technologies, and coastal foraging on California's Channel Islands. Science 331: 1181-1185.

Erlandson, J.M., T.C. Rick, T.L. Jones, and J.F. Porcasi. 2007. One if by land, two if by sea: who were the first Californians? Pages 53-62 in T.L. Jones and K.A. Klar, editors, California prehistory: colonization, culture and complexity. Altamira Press, Landam, MD.

Fitzhugh, B. 2003. The evolution of complex huntergatherers: archaeological evidence from the North Pacific. Kluwer Academic/Plenum Publishers, New York, NY.

Fitzhugh, B., AND D.J. KennetT. 2010. Seafaring intensity and island-mainland interaction along the Pacific Coast of North America. Pages 69-80 in A. Anderson, J. Barrett, and K. Boyle, editors, The global origins and development of seafaring. McDonald Institute for Archaeological Research, Cambridge, United Kingdom.

Fitzpatrick, S.M., M. Kappers, and Q. Kaye. 2006. Coastal erosion and site destruction on Carriacou, West Indies. Journal of Field Archaeology 31: 251-262.

FLADMARK, K.R. 1978. The feasibility of the northwest coast as a migration route for early man. Pages 119-128 in A.L. Bryan, editor, Early man in America from a circum-Pacific perspective. Archaeological Researches International, Edmonton, Alberta, Canada.

Fladmark, K.R. 1983. Times and places: environmental correlates of mid-to-late Wisconsinan human population expansion in North America. Pages 13-41 in R. Shutler, editor, Early man in the New World. Sage Publications, Beverly Hills, CA.

GLassow, M.A. 2004. Identifying complexity during the early prehistory of Santa Cruz Island, California. Pages 17-24 in J.E. Arnold, editor, Foundations of Chumash complexity. Cotsen Institute of Archaeology, Los Angeles, CA.

Glassow, M.A., T.J. Braje, J.G. Costello, J. Erlandson, J.R. Johnson, D.P. Morris, J.E. Perry, and T.C. Rick. 2010. Channel Islands National Park archaeological overview and assessment. Cultural Resources Division, Channel Islands National Park, Ventura, CA.

Griggs, G., K. Patsch, and L. Savoy, editors. 2005. Living with the changing California coast. University of California Press, Berkeley, CA.

Gruhn, R. 1988. Linguistic evidence in support of the coastal route of earliest entry into the New World. Man 23:77-100.

Haston, L., AND J. Michaelson. 1994. Long-term central coastal California precipitation variability and relationships to El Niño-Southern Oscillation. Journal of Climate 7:1373-1387.

Horton, R.E. 1945. Erosional development of streams and their drainage basins; hydrophysical approach to quantitative morphology. Geological Society of America Bulletin 56:275-370.
JAZWA, C.S. 2015. A dynamic ecological model for human settlement on California's northern Channel Islands. Doctoral dissertation, Pennsylvania State University, University Park, PA. 367 pp.

JAZWA, C.S. 2017. Coastal erosion and archaeological site formation processes on Santa Rosa Island, California. Pages 163-188 in A.L. Caporaso, editor, Formation processes of maritime cultural landscapes. Springer, Cham, Switzerland.

Jazwa, C.S., C.J. Duffy, L. Leonard, and D.J. Kennett. 2016a. Hydrological modeling and prehistoric settlement on Santa Rosa Island, California. Geoarchaeology: An International Journal 31:101-120.

Jazwa, C.S., D.J. Kennett, and B. Winterhalder. $2016 \mathrm{~b}$. A test of ideal free distribution predictions using targeted survey and excavation on California's northern Channel Islands. Journal of Archaeological Method and Theory 23:1242-1284.

Johnson, D.L. 1980. Episodic vegetation stripping, soil erosion, and landscape modification in prehistoric and recent historic time, San Miguel Island, California. Pages 103-121 in D.M. Power, editor, The California islands: proceedings of a multidisciplinary symposium. Santa Barbara Museum of Natural History, Santa Barbara, CA.

Johnson, J.R. 1982. An ethnographic study of the Island Chumash. Master's thesis, University of California, Santa Barbara, CA.

Johnson, J.R. 1993. Cruzeño Chumash social geography. Pages 19-46 in M.A. Glassow, editor, Archaeology on the northern Channel Islands of California. Coyote Press, Salinas, CA.

Johnson, J.R. 2001. Ethnohistoric reflections of Cruzeño Chumash society. Pages 21-52 in J.E. Arnold, editor, The origins of a Pacific coast chiefdom: the Chumash of the Channel Islands. University of Utah Press, Salt Lake City, UT.

Jones, T.L. 2002. Late Holocene cultural complexity on the California coast. Pages 1-12 in J.M. Erlandson and T.L. Jones, editors, Catalysts to complexity: late Holocene societies of the California coast. Volume 6, Perspectives in California Archaeology. Cotsen Institute of Archaeology, University of California, Los Angeles, CA.

Jones, T.L., AND K.A. KLAR. 2007. Colonization, culture, and complexity. Pages 299-315 in T.L. Jones and K.A. Klar, editors, California prehistory: colonization, culture, and complexity. Altamira, Lanham, MD.

KennetT, D.J. 2005. The Island Chumash, behavioral ecology of a maritime society. University of California Press, Berkeley, CA.

Kennett, D.J., J.P. KennetT, J.M. Erlandson, and K.G. Cannariato. 2007. Human responses to middle Holocene climate change on California's Channel Islands. Quaternary Science Reviews 26:351-367.

Kennett, D.J., J.P. Kennett, G.J. West, J.M. ErLandson, J.R. Johnson, I.L. Hendy, A. West, B.J. Culleton, T.L. Jones, and T.W. StafFord JR. 2008. Wildfire and abrupt ecosystem disruption on California's northern Channel Islands at the Allerød-Younger Dryas boundary (13.0-12.9 ka). Quaternary Science Reviews 27:2530-2545.

Kennett, D.J., and B. Winterhalder. 2008. Demographic expansion, despotism and the colonisation of east and south Polynesia. Pages 87-96 in G. Clark, F. Leach, and S. O'Connor, editors, Islands of inquiry: colonisation, seafaring and the archaeology 
of maritime landscapes (Terra Australis, 29). ANU E Press, Canberra, Australia.

Kennett, D.J., B. Winterhalder, J. Bartruff, and J.M. ERLANDSON. 2009. An ecological model for the emergence of institutionalized social hierarchies on California's northern Channel Islands. Pages 297-314 in S. Shennan, editor, Pattern and process in cultural evolution. University of California Press, Berkeley, CA.

KLEIN, R.G., AND D.W. BiRD. 2016. Shellfishing and human evolution. Journal of Anthropological Archaeology 44:198-205.

Klein, R.G., AND T.E. SteEle. 2013. Archaeological shellfish size and later human evolution in Africa. Proceedings of the National Academy of Sciences USA 110:10910-10915.

LEWIS, R.B. 2000. Sea-level rise and subsidence effects on Gulf Coast archaeological site distributions. American Antiquity 65:525-541.

Marean, C.W., M. Bar-Matthews, J. Bernatchez, E. Fisher, P. Goldberg, A. Herries, Z. Jacobs, A. Jerardino, P. Karkanas, T. Minichillo, ET AL. 2007. Early human use of maritime resources and pigment in South Africa during the middle Pleistocene. Nature 449:905-908.

Muhs, D.R., K.R. Simmons, L.T. Groves, J.P. McGeehin, R.R. Schumann, and L.D. Agenbroad. 2015. Late Quaternary sea-level history and the antiquity of mammoths (Mammuthus exilis and Mammuthus columbi), Channel Islands National Park, California, USA. Quaternary Research 83:502-521.

Muhs, D.R., K.R. Simmons, R.R. Schumann, L.T. Groves, S.B. DeVogel, S.A. Minor, and D. Laurel. 2014. Coastal tectonics on the eastern margin of the Pacific Rim: Late Quaternary sea-level history and uplift rates, Channel Islands National Park, California, USA. Quaternary Science Reviews 105: 209-238.

Muhs, D.R., G. Skipp, R.R. Schumann, D.L. Johnson, J.P. McGeehin, J. Beann, J. Freeman, T.A. Pearce, and Z.M. RowLand. 2009. The origin and paleoclimatic significance of carbonate sand dunes deposited on the California Channel Islands during the last glacial period. Pages 3-14 in C.C. Damiani and D.K. Garcelon, editors, Proceedings of the 7th California Islands Symposium. Institute for Wildlife Studies, Arcata, CA.

Murphy, P., D. Thackray, and E. Wilson. 2009. Coastal heritage and climate change in England: assessing threats and priorities. Conservation and Management of Archaeological Sites 11:9-15.

[NASA] National Aeronautics and Space AdministraTION. 2015. NASA studying $2015 \mathrm{El}$ Niño event as never before. [Accessed 13 December 2015]. https:// www.nasa.gov/feature/goddard/nasa-studying-2015 -el-nino-event-as-never-before

[NOAA] National OCEanographic and Atmospheric Administration. 2016a. El Niño/Southern Oscillation (ENSO) diagnostic discussion [electronic document]. [Accessed 17 November 2016]. http://www .cpc.ncep.noaa.gov/products/analysis_monitoring/enso advisory/ensodisc.html

[NOAA] National OCEanographic and Atmospheric Administration. 2016b. April 2016 El Niño/La Niña update: what goes up... [Accessed 17 November 2016]. https://www.climate.gov/news-features/blogs/ enso/april-2016-el-niñola-niña-update-what-goes-...
O’Connell, J.F., And F. Allen. 2012. The restaurant at the end of the universe: modelling the colonisation of Sahul. Australian Archaeology 74:5-17.

PARKington, J. 1981. The effects of environmental change on the scheduling of visits to the Elands Bay Cave, Cape Province, S.A. Pages 341-359 in I. Hodder, G. Isaac, and N. Hammond, editors, Pattern of the past. Cambridge University Press, Cambridge.

Pendleton, E.A.E., R. Thieler, and S.J. Williams. 2005. Coastal vulnerability assessment of Channel Islands National Park (CHIS) to sea-level rise. United States Geological Survey.

Perroy, R.L., B. Bookhagen, and O.A. Chadwick. 2012. Holocene and Anthropocene landscape change: arroyo formation on Santa Cruz Island, California. Annals of the Association of American Geographers 102:1229-1250

Philander, G.S. 1990. El Niño, La Niña, and the Southern Oscillation. Academic Press, San Diego, CA.

Pinter, N., B. Johns, AND B. LitTLe. 2001. Fault-related folding in California's northern Channel Islands documented by rapid-static GPS positioning. GSA Today 11(5):4-9.

Quilter, J., And T. Stocker. 1983. Subsistence economies and the origins of Andean complex societies. American Anthropologist 85:545-562.

RaAB, L.M., AND D.O. LARSON. 1997. Medieval Climatic Anomaly and punctuated cultural evolution in coastal southern California. American Antiquity 62: 319-336.

Ramage, C.S. 1986. El Niño. Scientific American 254: $76-83$.

ReEder, L.A., T.C. Rick, AND J.M. ERLANDSOn. 2012. Our disappearing past: a GIS analysis of the vulnerability of coastal archaeological resources in California's Santa Barbara Channel region. Journal of Coastal Conservation 16:187-197.

Reeder-Myers, L.A. 2015. Cultural heritage at risk: a vulnerability assessment of coastal archaeological sites in the United States. Journal of Island and Coastal Archaeology 10:436-445.

Reeder-Myers, L., J.M. Erlandson, D.R. Muhs, and T.C. RicK. 2015. Sea level, paleogeography, and archaeology on California's northern Channel Islands. Quaternary Research 83:263-272.

Rick, T.C., J.M. Erlandson, T.J. Braje, J.A. Estes, M.H. Graham, and R.L. Vellanoweth. 2008. Historical ecology and human impacts on coastal ecosystems of the Santa Barbara Channel region, California. Pages 77-101 in T.C. Rick and J.M. Erlandson, editors, Human impacts on ancient marine ecosystems. University of California Press, Berkeley, CA.

Rick, T.C., J.M. ERlandson, and R.L. Vellanoweth. 2006. Taphonomy and site formation on California's Channel Islands. Geoarchaeology: An International Journal 21:567-589.

Robinson, M.H., C.R. Alexander, C.W. Jackson, C.P. McCABE, AND D. CRASS. 2010. Threatened archaeological, historic, and cultural resources of the Georgia coast: identification, prioritization and management using GIS technology. Geoarchaeology 25:312-326.

Sandweiss, D.H., K.A. Maasch, R.L. Burger, J.B. Richardson III, H.B. Rollins, and A. Clement. 2001. Variation in Holocene El Niño frequencies: climate records and cultural consequences in Ancient Peru. Geology 29:603-606. 
Schoenherr, A.A., C.R. Feldmeth, and M.J. Emerson. 1999. Natural history of the islands of California. University of California Press, Berkeley, CA.

Schumann, R.R., S.A. Mionr, D.R. Muhs, And J.S. Pigati. 2014. Landscapes of Santa Rosa Island, Channel Islands National Park, California. Monographs of the Western North American Naturalist 7:48-67.

Schumann, R.R., J.S. Pigati, and J.P. McGeehin. 2016. Fluvial system response to late PleistoceneHolocene sea-level change on Santa Rosa Island, Channel Islands National Park, California. Geomorphology 268:322-340.

Shi, B., J.N. Proust, M.Y. Daire, E. Lopez-Romero, H. Regnauld, and S. Pian. 2012. Coastal changes and cultural heritage (2): an experiment in the Vilaine Estuary (Brittany, France). Journal of Island and Coastal Archaeology 7:183-199.

Sмith, M. 2013. The archaeology of Australia's deserts. Cambridge World Archaeology, Cambridge.

Sorlien, C.C. 1994. Faulting and uplift of the northern Channel Islands, California. Pages 282-296 in The Fourth California Islands Symposium: update on the status of resources. Santa Barbara Museum of Natural History, Santa Barbara, CA.

Stringer, C. 2000. Coasting out of Africa. Nature 405: 24-27.

Thieler, R.E., and E.S. Hammar-Klose. 2000. National assessment of coastal vulnerability to sea-level rise: preliminary results for the U.S. Pacific coast. U.S. Geological Survey, Open-File Report 00-178. van Andel, T.H. 1989. Late Pleistocene sea levels and the human exploitation of the shore and shelf of southern South Africa. Journal of Field Archaeology 16: $133-155$.

Veth, P., I. Ward, and T. Manne. 2017. Coastal feasts: a Pleistocene antiquity for resource abundance in the maritime deserts of north west Australia. Journal of Island and Coastal Archaeology 12:8-23.

Walter, R.C., R.T. Buffler, J.H. Bruggemann, M.M.M. Guillaume, S.M. Berhe, B. Negassi, Y. Libsekal, H. Cheng, R.L. Edwards, R. von Cosel, et al. 2000. Early human occupation of the Red Sea coast of Eritrea during the Last Interglacial. Nature 405: $65-69$.

Westley, K., T. Bell, M.A.P. Renouf, and L. Tarasov. 2011. Impact assessment of current and future sealevel change on coastal archaeological resourcesillustrated examples form northern Newfoundland. Journal of Island and Coastal Archaeology 6: 351-374.

Winterhalder, B., D.J. Kennett, M.N. Grote, and J. BARTRUFF. 2010. Ideal free settlement of California's northern Channel Islands. Journal of Anthropological Archaeology 29:469-490.

Received 1 March 2017

Revised 18 October 2017

Accepted 23 October 2017

Published online 30 October 2018 